\title{
Benthic decomposition rates and pathways in plantations of the mangrove Rhizophora apiculata in the Mekong delta, Vietnam
}

\author{
D. M. Alongi ${ }^{1, *}$, F. Tirendi ${ }^{1}$, L. A. Trott $^{1}$, T. T. Xuan ${ }^{2}$

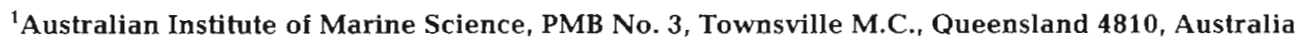 \\ ${ }^{2}$ Research Institute for Aquaculture No. 2, 116 Nguyen Dinh Chieu St., District 1, Ho Chi Minh City, Vietnam
}

\begin{abstract}
Rates and pathways of organic matter decomposition were estimated in sediments of 6,8 and 35 yr old Rhizophora apiculata plantations in the lower Mekong delta, Vietnam. Rates of total carbon oxidation $\left(\mathrm{T} C \mathrm{Cx}=\right.$ average of $\mathrm{CO}_{2}$ gas fluxes from exposed sediments $+\Sigma \mathrm{CO}_{2}$ fluxes from submerged sediments) were slowest in the $8 \mathrm{yr}$ old forest (mean $\mathrm{T}_{\mathrm{Cox}}=17.1 \mathrm{mmol} \mathrm{C} \mathrm{m} \mathrm{d}^{-1}$ ), with higher rates in the 6 yr old (mean $\mathrm{T}_{\mathrm{cox}}=48.1 \mathrm{mmol} \mathrm{C} \mathrm{m}^{-2} \mathrm{~d}^{-1}$ ) and $35 \mathrm{yr}$ old forests (mean $\mathrm{T}_{\mathrm{Cox}}=53.7 \mathrm{mmol}$ $\mathrm{C} \mathrm{m}^{-2} \mathrm{~d}^{-1}$ ). In all 3 forests, sediments to a depth of $40 \mathrm{~cm}$ were acidic, with mostly positive redox potential; free sulfides and methane were not measurable in the pore water or across the sediment/water-air interface. Oxic respiration was the major decomposition pathway, ranging from 63 to $64 \%$ of $\mathrm{T}_{\mathrm{COx}}$ in the 2 older forests to $94 \%$ of $\mathrm{T}_{\mathrm{Cox}}$ in the $6 \mathrm{yr}$ old stand. Budget calculations suggest that most of the $\mathrm{O}_{2}$ flux was associated with chemical oxidation in sediments of the 2 youngest forests. Sulfate reduction was the second most important diagenetic pathway (range 0.2 to $13.0 \mathrm{mmol} \mathrm{S} \mathrm{m} \mathrm{m}^{-1}$ ) and, on average, total rates increased with increasing forest age. Manganese reduction appeared to be a minor decomposition pathway in all 3 stands (range 1.0 to $2.8 \mathrm{mmol} \mathrm{Mn} \mathrm{m}^{-2} \mathrm{~d}^{-1}$ ), and iron reduction was measurable only in the 6 yr old forest $\left(0.9 \pm 0.6 \mathrm{mmol} \mathrm{Fe} \mathrm{m} \mathrm{m}^{-2} \mathrm{~d}^{-1}\right)$. Denitrification was measurable only in the $35 \mathrm{yr}$ old forest $\left(2.2 \pm 0.5 \mathrm{mmol} \mathrm{N}_{2} \mathrm{~m}^{-2} \mathrm{~d}^{-1}\right)$, but was the third largest C oxidation pathway at this site. Nitrogen fixation was most rapid in the 8 yr old forest $\left(1425 \pm 468 \mu \mathrm{mol} \mathrm{N}_{2} \mathrm{~m}^{-2} \mathrm{~d}^{-1}\right)$ and equivalent in the 6 yr old $\left(245 \pm 127 \mu \mathrm{mol} \mathrm{N} \mathrm{m}^{-2} \mathrm{~d}^{-1}\right)$ and 35 yr old forests $\left(444 \pm 92 \mu \mathrm{mol} \mathrm{N} \mathrm{m}^{-2} \mathrm{~d}^{-1}\right)$. The molar carbon ratio of sediment respiration to forest net primary production $\left(\mathrm{R}_{\text {hetero }} / \mathrm{NPP}\right)$ in the 6 and $35 \mathrm{yr}$ old forests averaged 18 and $28 \%$, respectively. These comparatively low mineralization losses, coupled with the lack of measurable denitrification at 2 of the 3 plantations, imply that these $R$. apiculata plantations are highly efficient at sequestering labile carbon and nitrogen into plant biomass and sediment pools.
\end{abstract}

KEY WORDS: Mangrove - Decomposition - Respiration · Sediment - Benthic Rhizophora C Carbon · Nitrogen

\section{INTRODUCTION}

Mangrove forests help to sustain coastal food chains and nutrient cycles, and are an important source of timber, fuel, food, and other products for human inhabitants in tropical coastal regions (Field 1995). Traditional uses of mangrove wood include production of charcoal, tannins for dyeing and leather protection, furniture, poles, and thatch for houses.

\footnotetext{
•E-mail: d.alongi@aims.gov.auu
}

In Southeast Asia, such traditional use of mangroves is common, but there are other forms of exploitation that are more destructive on an ever-increasing scale. Removal of mangroves for economic and commercial purposes, such as construction of shrimp and fish ponds, timber extraction for wood-chipping, construction of tourist facilities, industrial and road development, mining, and drainage for agriculture and flood protection, is occurring at an unsustainable level (Field 1995, Hinrichsen 1998).

In Vietnam, where mangrove forests once covered an area of $4000 \mathrm{~km}^{2}$, the widespread use of herbicides 
and napalm during the Vietnam War destroyed nearly $1050 \mathrm{~km}^{2}$ of mangrove forest (Hong \& San 1993). Most of the remaining mangrove forests occupy the Mekong delta, and consist mostly of secondary communities and plantations (Spalding et al. 1997). Coastal erosion has occurred in many parts of the Mekong delta, where mangrove forests have not regenerated because of degraded soils or have formed secondary scrubby growth. There have been further losses of mangrove forest since the Vietnam War through conversion of land to shrimp ponds, salt ponds, and rice agriculture (Hong \& San 1993). From 1977 to 1995, the area of mangrove forest in Minh Hai Province in the Mekong region has declined from 84127 to 64819 ha (DeGraaf \& Xuan 1998). Based on projections of the Minh Hai Forestry Department, at the current rate of loss ( 5000 ha $\mathrm{yr}^{-1}$; Hong \& San 1993), mangrove forests will not be able to meet the projected demand for firewood. These additional losses have led to other problems such as salinity intrusion, acidification of coastal and aquaculture waters, a decline in abundance of post-larval shrimp and the mud crab Scylla serrata, and a decline in shrimp pond yields (Alongi et al. 1999b, Johnston et al. 1999).

In an effort to stem the decline of mangrove forests and to improve yields of both mangrove timber and cultured shrimp, the Minh Hai government established 22 mixed shrimp farming-mangrove forestry enterprises (SFFEs), whereby both shrimp and mangroves are cultured by individual farmers on small plots of not more than 10 to $15 \mathrm{ha}$. Only the tall-stilted mangrove, Rhizophora apiculata, is cultured as plantations within these enterprises.

As part of a large project to identify and ameliorate the factors causing declining yields of shrimp and mangrove wood (Johnston et al. 1999), we investigated how sediment chemistry, and rates and pathways of organic-matter decomposition in sediments influence the potential yield from these mangrove plantations. Recent studies on other mangrove forests indicate a positive relationship between rates of benthic remineralization and mangrove productivity (Alongi 2000) and differences in the specific pathways of organic matter decomposition with forest age (Alongi et al. 1998). These plant-microbial links are reflected in clear evidence that highly productive mangrove forests serve as sinks for many species of dissolved nutrients (Boto 1992, Kristensen et al. 1995, 1998, Rivera-Monroy \& Twilley 1996, Duarte et al. 1998). Mangrove-microbenutrient interrelationships are complex (Boto 1992, Nedwell et al. 1994) and need to be more fully understood in order to assist managers in maximizing mangrove yields. In this paper, we examine sediment biogeochemistry in 6,8 , and $35 \mathrm{yr}$ old plantations of Rhizophora apiculata in the lower Mekong delta.

\section{MATERIALS AND METHODS}

Study sites. The 6 and 8 yr old Rhizophora apiculata forests are located on separate plantations within Enterprise Tam Giang III (latitude $8.8^{\circ} \mathrm{N}$, longitude $\left.105.2^{\circ} \mathrm{E}\right)$, located in Minh Hai province on the Ca Mau peninsula of the lower Mekong delta (Fig. 1). Tam Giang III consists of many extensive farms practicing 2 types of cultivation: (1) separate shrimp pond and mangrove forest farms; (2) mixed farms where the shrimp ponds consist of a series of long channels dug through the mangrove forest (Alongi et al. 1999b, Johnston et al. 1999). The 6 yr old forest (Stn M6, Fig. 1) is located on a mixed model farm through which canals for shrimp aquaculture have been dug. This forest (10.5 ha) was manually replanted, but not thinned. Above-ground biomass for this forest averages 78.3 metric tons $\mathrm{ha}^{-1}$ with an average net primary production of 23 metric tons ha $\mathrm{a}^{-1} \mathrm{yr}^{-1}$ (B. F. Clough pers. comm.). The 8 yr old forest (Stn M8, Fig. 1) is located on a separate farm-model system in which the forest (5.6 ha) has been allowed to regenerate naturally behind the shrimp pond. This stand has not been thinned. It has an average above-ground biomass of 90 metric tons $\mathrm{ha}^{-1}$; net primary production for this stand is unknown. The third study site (Stn M35) is a $35 \mathrm{yr}$ old $R$. apiculata forest ( $-50 \mathrm{ha}$ ) located along a man-made canal (Fig. 1), and is used as a source of propagules for other plantations. This stand was manually planted and thinned by $30 \%$ in 1993. Aboveground biomass for this forest is 325.6 metric tons ha ${ }^{-1}$, with an average net primary production of 16.6 metric tons ha ${ }^{-1} \mathrm{yr}^{-1}$ (B. F. Clough pers. comm.).

All 3 plantations are located in the high intertidal zone (defined as the zone inundated by mean highwater spring to extreme high-water spring tides; Alongi 1989). These forests are inundated by tides only $\sim 3$ to $5 \mathrm{~d} \mathrm{mo}^{-1}$ (Xuan, Hoang \& Hung pers. obs.). Topographical data are not available for this area, but the average annual tidal range is $\sim 1.8$ to $2.0 \mathrm{~m}$ (Thuy 1988 , Wolanski et al 1996).

Sediment chemistry. In October 1996, sediment cores for pore water and solid-phase elements $(n=3)$ and for redox potential and $\mathrm{pH}(\mathrm{n}=2)$ were taken at each site using a $40 \mathrm{~cm}$ long, stainless steel corer $(7 \mathrm{~cm}$ i.d.) containing an inner core subdivided into $2 \mathrm{~cm}$ long plastic rings. Cores were taken randomly from each forest. Sediment temperature, $\mathrm{Eh}$, and $\mathrm{pH}$ were measured to a depth of $40 \mathrm{~cm}(2 \mathrm{~cm}$ intervals) with a Model ATC temperature probe, a Model PRFO combination calomel reference-platinum redox electrode, and a Model PBFC pH probe (TPS Pty. Ltd, Brisbane, Australia). The redox and $\mathrm{pH}$ electrodes were allowed to equilibrate for 10 to $15 \mathrm{~min}$ before readings were taken with a TPS $^{\circ}$ Model WP-80D mV-pH-temperature me- 
ter The $\mathrm{pH}$ electrode was calibrated with $5.00,6.00$ and 7.00 standards. The water content of triplicate $5 \mathrm{~cm}^{3}$ samples taken to a depth of $20 \mathrm{~cm}$ ( $2 \mathrm{~cm}$ intervals) was determined as difference in weight loss of wet sediment dried at $80^{\circ} \mathrm{C}$ for $16 \mathrm{~h}$. The percentage of sand, silt and clay was determined by sieve and pipette analysis on duplicate bulk (0 to $10 \mathrm{~cm}$ ) samples (Folk 1974).

For pore water, triplicate cores were sliced at 2 or $4 \mathrm{~cm}$ intervals in a glove bag under $\mathrm{N}_{2}$ atmosphere, with each sediment slice kept intact, and placed into an acidwashed Petri dish. The intact slices were placed immediately into Teflon pore-water extractor cassettes (Robbins \& Gustinis 1976 ) and squeezed to obtain $\sim 10 \mathrm{ml}$ pore water per sample (see procedures in Alongi et al. 1998, 1999a,b). The pore water samples were analyzed for $\mathrm{SO}_{4}, \mathrm{Cl}^{-}$, Fe, $\mathrm{Mn}, \mathrm{DOC}, \mathrm{PO}_{4}, \mathrm{NH}_{4}{ }^{+}, \mathrm{NO}_{2}^{-}+\mathrm{NO}_{3}{ }^{-}$and $\mathrm{HS}^{-}$. Sulfate and sulfide were measured in pore water to which $1 \mathrm{ml} 20 \%$ zinc acetate had been added as fixative. Sulfide was measured spectrophotometrically from precipitated ZnS (Cline 1969). Sulfate was determined gravimetrically by $\mathrm{BaSO}_{4}$ precipitation and filtration. Average precision for $\mathrm{SO}_{4}$ and $\mathrm{HS}^{-}$was $3 \%$. Dissolved inorganic nutrients were determined by standard automated techniques (Ryle et al. 1981, Ryle \& Wellington 1982). DOC, Fe and $\mathrm{Mn}$ were measured on pore water stored cool in sterile polypropylene test tubes. DOC was determined by hightemperature catalytic oxidation on a Shimadzu TOC-5000 Analyzer (Hedges et al. 1993). Blanks using Milli-Q water were run for DOC concurrently with the samples. Dissolved $\mathrm{Fe}$ and $\mathrm{Mn}$ were measured on a Varian Liberty 220 ICP-AES, with analytical precision of \pm 1.5 and $0.09 \mu \mathrm{M}$, respectively. Chloride was measured on the same samples using a Radiometer CMT10 Chloride Titrator.

Solid-phase elements (TOC, total N, P, S, Fe, Mn, $\mathrm{FeS}_{2}$ ) were determined in the same sediment slices squeezed for pore water. After drying and grinding, TOC was determined on a Beckman TOC Analyzer and total $\mathrm{N}$ on a Perkin Elmer $2400 \mathrm{CHNS/O}$ Series II Analyzer. Total P, S, Fe and Mn were measured on the Varian ICP-AES after aqua regia and $\mathrm{HClO}_{4}$ digestion. Pyrite was measured by the spectrophotometric method of Lord (1982).
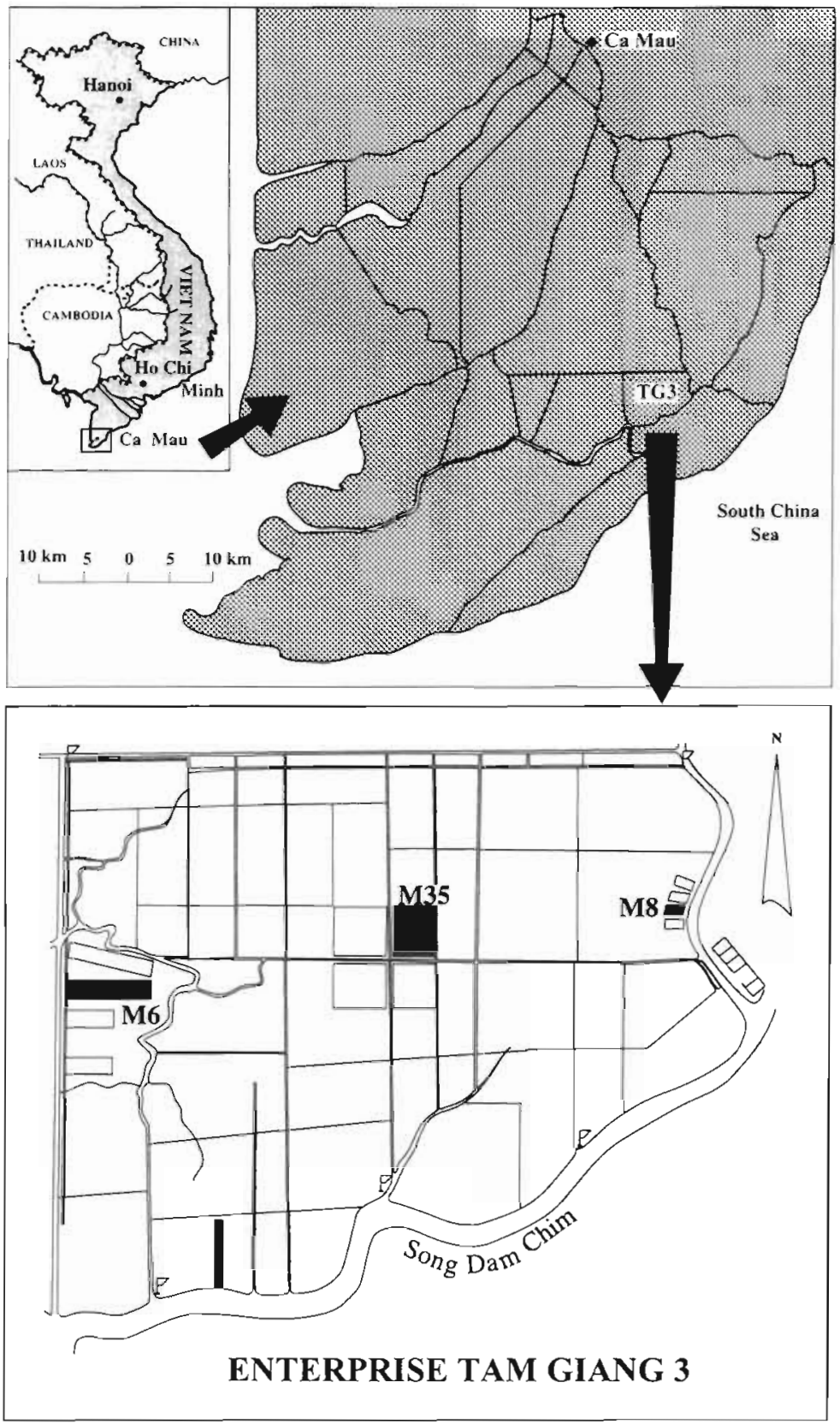

Fig. 1. Location of Stns M6, M8 and M35 within enterprise Tam Giang III (TG3), and enterprise location within lower Mekong delta, Vietnam

Methane concentration in the pore water was determined in November 1997 by slicing triplicate $1 \mathrm{~m}$ long cores fusing a $1.5 \mathrm{~m}$ long, $7 \mathrm{~cm}$ i.d. stainless-steel corer) and analyzing subsamples at 5 to $10 \mathrm{~cm}$ intervals. These segments were placed in plastic syringes containing $20 \mathrm{ml}$ of a $1 \mathrm{M} \mathrm{NaOH}$ solution; samples were sealed with a rubber-stoppered plunger, shaken and allowed to sit at ambient temperature for $\sim 1 \mathrm{~h}$ (Ferdelman et al. 1997). Gas in the headspace was examined by gas chromatography (thermal conduc- 
tivity detection, GC-TCD) by extruding headspace gas directly into the sampling port of a MTI Analytical Instruments P200 gas chromatograph. Pure methane gas was used as standard. Analytical precision ( $\pm 1 \mathrm{SE}$ ) was $\pm 10 \%$.

Metal reduction. Net rates of iron and manganese reduction were estimated in November 1997 with a core-incubation method (Aller et al. 1996). Two sets of duplicate $20 \mathrm{~cm}$ long cores were subdivided into $4 \mathrm{~cm}$ long sections under a $\mathrm{N}_{2}$ atmosphere. The sections were placed into separate sterile and air-tight opaque plastic boxes, each containing $20 \mathrm{ml}$ deoxygenated sodium molybdate ( $20 \mathrm{mM}$ ) solution, to inhibit sulfate reduction. Sediments in each box were mixed and subsampled on Days 0, 1, 2 and 3. Subsamples were placed directly into the pore-water squeezer cassettes, removed from the glove box, and processed as for other pore-water solutes. Total dissolved Fe and Mn were determined on a Varian Liberty 220 ICP-AES.

Sulfate reduction. In October 1996 and May 1997, sulfate reduction was measured on triplicate $2.7 \mathrm{~cm}$ diameter cores using the core-injection technique (Fossing \& Jorgensen 1989). Injections of $2 \mathrm{ml}$ carrierfree ${ }^{35} \mathrm{SO}_{4}{ }^{2-}$ (74 MBq ml-1 ; Amersham, England) were made horizontally at $1 \mathrm{~cm}$ intervals through siliconestoppered ports. The cores were incubated in shade for $6 \mathrm{~h}$ ( $4 \mathrm{~h}$ at Stn M35 in 1997) before being cut into $2 \mathrm{~cm}$ segments, transferred to $20 \% \mathrm{ZnAc}$, and frozen to terminate incubations and fix sulfides. A 2-step distillation procedure was used to determine the fraction of reduced radiolabel in the acid-volatile sulfide (AVS = free sulfides, FeS) and chromium-reducible sulfur (CRS $=\mathrm{S}^{0}, \mathrm{FeS}_{2}$ ) pools (Fossing \& Jorgensen 1989).

Denitrification. Denitrification was measured from replicate cores taken in May 1997 (Stns M6 and M8) and November 1997 (Stn M35) using the $\mathrm{N}_{2}$-gas flux technique of Nowicki (1994). Sediment cores (volume range 230 to $385 \mathrm{~cm}^{3}$, sediment-depth range 6 to $10 \mathrm{~cm}$ ) were taken by pushing open-ended plastic bottles into the sediment surface and placing each core in a gas-tight glass chamber (height $23.5 \mathrm{~cm}$; i.d. $7.6 \mathrm{~cm}$ ). Sediments in each chamber were covered with $\sim 500$ to $800 \mathrm{ml}$ seawater collected from an adjacent estuary. Each chamber was sparged with either an $80 \% \mathrm{He} /$ $20 \% \mathrm{O}_{2}$ mixture ( 3 experimental chambers per site) or $100 \% \mathrm{He}$ ( 1 to 2 control chambers per site, see below) to remove $\mathrm{N}_{2}$ and, in the case of the experimental cores, to maintain dissolved $\mathrm{O}_{2}$ concentrations. The overlying water in each sealed chamber was stirred continuously. All chambers were incubated for $9 \mathrm{~d}$ at ambient temperatures to mimic field conditions.

In the experimental chambers, the gas phase was flushed repeatedly with a $80 \% \mathrm{He} / 20 \% \mathrm{O}_{2}$ mixture after the overlying water had been periodically replaced with low- $\mathrm{N}_{2}$ seawater. The water exchanges maintained oxygen conditions and an adequate nitrate supply.

The control chambers were incubated under anaerobic conditions $(100 \%$ He gas and deoxygenated-water exchanges) in order to block nitrification and denitrification (Nowicki 1994). Water exchanges were made on Days 3 and 6. After each water exchange, the gas headspace was flushed with $100 \%$ He for 3 to 5 min twice within $8 \mathrm{~h}$, followed by $24 \mathrm{~h}$ incubation before the accumulated of $\mathrm{N}_{2}$ gas in the headspace was measured. Gas-flushing occurred daily, and the accumulation of $\mathrm{N}_{2}$ gas in the headspace was measured each day over the $9 \mathrm{~d}$ incubation period.

Despite denitrification being blocked in the control cores, there can be significant de-gassing of $\mathrm{N}_{2}$ from the sediment pore water that diffuses into the overlying water and gas. This background flux of $\mathrm{N}_{2}\left\{F_{\mathrm{dg}}\right\}$ measured in the control chambers was subtracted from the total $\mathrm{N}_{2}$ flux $\left(F_{\mathrm{t}}\right)$ measured in the experimental chambers to derive the rate of $\mathrm{N}_{2}$ flux due to denitrification $\left(F_{\mathrm{dn}}\right)$, where $F_{\mathrm{dn}}=F_{\mathrm{t}}-F_{\mathrm{dg}}$ (Nowicki 1994). Denitrification rates ( $\mu$ mol $\mathrm{N}_{2} \mathrm{~m}^{-2} \mathrm{~d}^{-1}$ ) were calculated as the average rate of triplicate cores from each site, from 3 to 4 data points over the $9 \mathrm{~d}$ incubations.

Measurements of $\mathrm{N}_{2}$ and $\mathrm{O}_{2}$ concentrations in the overlying gas phase in each chamber were made by withdrawing samples through the chamber samplingports by an He-flushed syringe. The gas was analyzed for $\mathrm{N}_{2}$ and $\mathrm{O}_{2}$ using an MTI Analytical Instruments P200 gas chromatograph under conditions specified by Nowicki (1994). Calibration standards were run with each set of samples using a gas mixture $\left(3 \% \mathrm{~N}_{2}, 20 \%\right.$ $\mathrm{O}_{2}, 77 \% \mathrm{He}$ ) certified by BOC Gases Australia Ltd (Townsville, Australia).

Nitrogen fixation. Nitrogen fixation in each forest was measured in November 1997 in replicate $(n=8)$ darkened chambers (see 'Gas and solute fluxes' below) using the acetylene-reduction technique (Capone 1993). Acetylene and ethylene in the incubation mixtures were analyzed simultaneously by gas chromatography. The acetylene-reduction rates were converted to rates of nitrogen fixation using the theoretical factor of 3 acetylene molecules equivalent to 1 nitrogen molecule.

Gas and solute fluxes. Fluxes of $\sum \mathrm{CO}_{2}, \mathrm{DOC}, \mathrm{Fe}, \mathrm{Mn}$, DOC, DON, DOP, $\mathrm{NH}_{4}{ }^{+}, \mathrm{NO}_{2}{ }^{-}+\mathrm{NO}_{3}{ }^{-}$, and $\mathrm{PO}_{4}{ }^{3-}$ across the sediment-water interface were made from triplicate glass chambers (surface area $=0.007 \mathrm{~m}^{2}$ ) inserted into boxcorer samples and incubated in a shaded water bath at ambient temperature (Alongi et al. 1998, 1999a,b). Each boxcore liner was inserted into the forest floor to a depth of $25 \mathrm{~cm}$, and removed with minimal disturbance. Each chamber had a propellerelectric motor unit and 2 sampling ports. Samples for dissolved metals and nutrients were taken from each 
chamber via the sampling ports. Samples were taken at $30 \mathrm{~min}$ intervals for $3 \mathrm{~h}$. Filtering and processing of metal samples were identical to procedures for porewater metals. Fluxes of all solutes were measured at each forest in May and November 1997, except for $\sum \mathrm{CO}_{2}$ which was measured only in November 1997 $\Sigma \mathrm{CO}_{2}$ was estimated as the difference between measurements on each filtered (0.4 $\mathrm{mm}$ Nuclepore) sample of total dissolved carbon and dissolved organic carbon after acidification with $100 \mu$ highpurity $\mathrm{HCl}$. Samples were measured on a Shimadzu TOC-5000 Analyzer.

Three opaque-glass chambers per site were used to measure $\mathrm{CO}_{2}, \mathrm{O}_{2}$, and $\mathrm{CH}_{4}$ fluxes across the air-sediment interface in May and November 1997. These chambers were incubated in a shaded water bath with ambient seawater up to several $\mathrm{cm}$ below the sediment surface. Gas samples were taken at 30 min intervals over $3 \mathrm{~h}$ from a sampling port on each chamber, and were analyzed by GC-TCD (see 'Sediment chemistry' above) using certified standards. Average precision was $0.3 \%$ for $\mathrm{O}_{2}, 0.4 \%$ for $\mathrm{CO}_{2}$ and $5 \%$ for $\mathrm{CH}_{4}$.

Data analysis. Comparisons between sites and sampling times were made using either 1- or 2-factor ANOVA (Sokal \& Rohlf 1995). Any significant site or season effects were further examined using the Student-Newman-Keuls test. Data were log-transformed if $F_{\max }$ tests indicated heteroscedasticity. Linear regression was used to calculate rates of solute and gas flux. Level of significance was $\mathrm{p}=0.05$.

\section{RESULTS}

\section{Sediment chemistry}

Sediment temperature at all 3 Rhizophora apiculata forests ranged from 29 to $33^{\circ} \mathrm{C}$ with no significant seasonal differences among forests. At Stns M6 and M35, sediments consisted of equal parts of silt and clay with no sand. Stn M8 sediments were comprised of $66.7 \%$ silt and $33.3 \%$ clay. The water content of sediments at all 3 sites averaged $9.5 \%$ at Stns M6 and M35 and $14.5 \%$ at Stn M8. At all 3 sites, sediments below $\sim 40 \mathrm{~cm}$ consisted of hard, grey clay, with no roots or other mangrove material. Subsamples of this

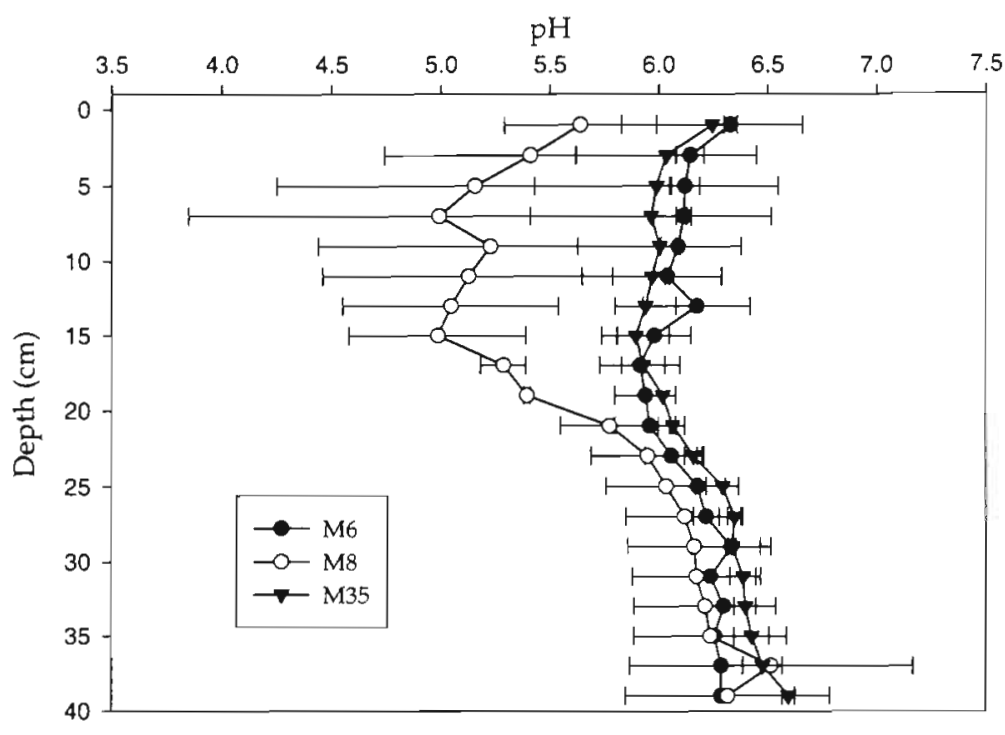

Fig. 2. Rhizophora apiculata forests. Vertical pH profiles (means $\pm 1 \mathrm{SE}$ ) at $2 \mathrm{~cm}$ intervals to a sediment depth of $40 \mathrm{~cm}$ at Stns M6, M8, and M35, October 1996

grey clay measured for TOC consisted of little, if any, organic carbon $(<0.1 \%$ by sediment dry $w \mathrm{t}$ ).

Sediments at all sites were acidic (Fig, 2) and generally non-reducing (Fig. 3). Differences in $\mathrm{pH}$ and redox potential among forests were not significant because of large between-core variations. On average, however, Stn M8 sediments were the most acidic, particularly over the 0 to $20 \mathrm{~cm}$ horizon. Sediment $\mathrm{pH}$ at all sites was $<7.0$. Redox levels were $>0$ at all forests and depths, except below $15 \mathrm{~cm}$ at Stn M6 (Fig. 3).

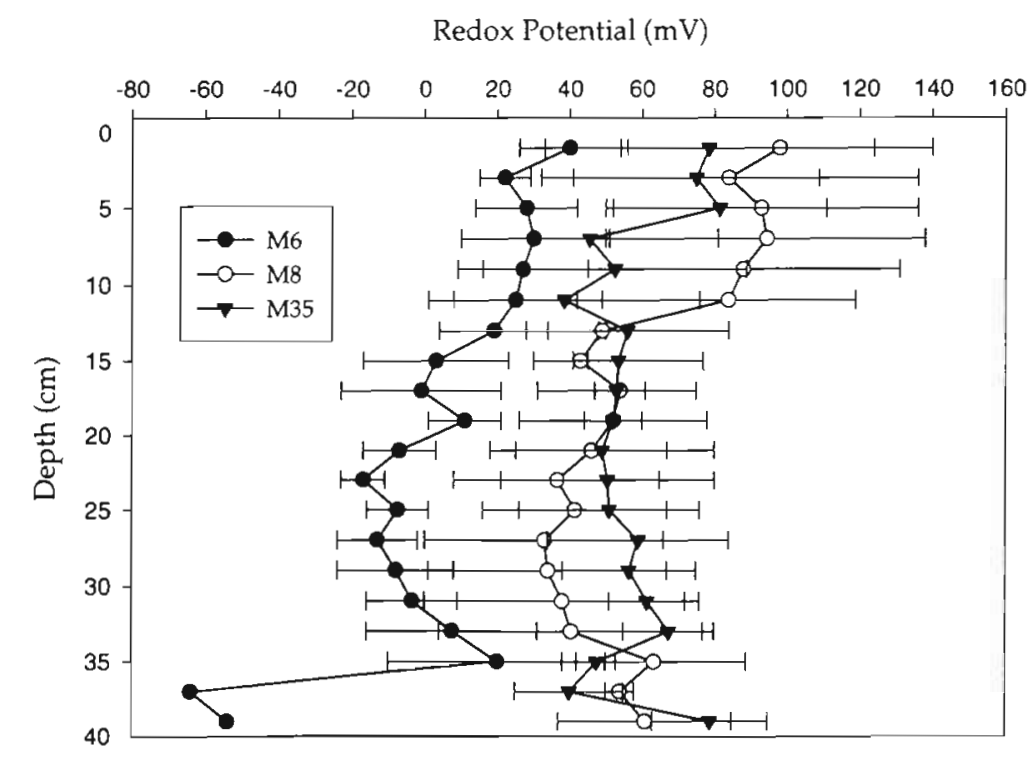

Fig. 3. Rhizophora apiculata forests. Vertical profiles (means $\pm 1 \mathrm{SE}$ ) of redox potential at $2 \mathrm{~cm}$ intervals to sediment depth of $40 \mathrm{~cm}$ at $S$ tns $M 6, M 8$, and M35, October 1996 
Pore water at most depths at all 3 sites (Fig. 4) showed greater $\mathrm{SO}_{4} / \mathrm{Cl}$ ratios than in the overlying water (see arrow in Fig. 4), despite greater levels of $\mathrm{Cl}^{-}$ in the pore water than in the adjacent creek water
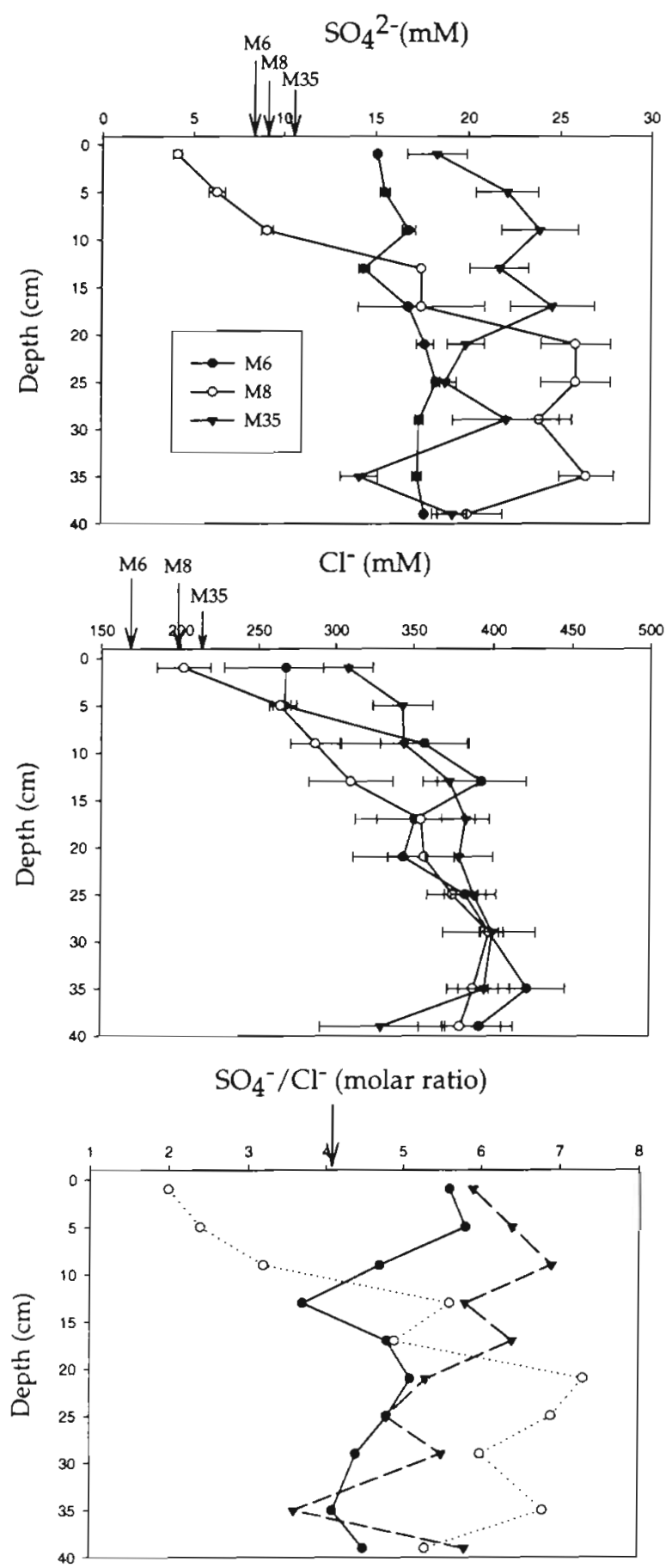

Fig. 4. Rhizophora apiculata forests. Vertical profiles (means \pm 1 SE) of pore-water sulfate, chloride and sulfate/chloride ratio for all 3 forests, October 1996. Arrows on $x$-axis: mean values in overlying water at each site; single arrow: $\mathrm{SO}_{4} / \mathrm{Cl}$ ratios in all tidal waters (i.e. no significant differences among locations)
(Fig. 4). $\mathrm{No} \mathrm{HS}^{-}$or $\mathrm{CH}_{4}$ were detected in the pore water at any depth at any of the 3 forests.

Vertical profiles of pore water $\mathrm{NH}_{4}{ }^{+}, \mathrm{PO}_{4}{ }^{3-}$, DOC, $\mathrm{Fe}$ and $\mathrm{Mn}$ concentrations were highly variable at each forest, with no significant differences in concentrations among replicate cores (Table 1). The only significant differences among the 3 forests were lower concentrations of Fe and DOC at Stn M6 than at the other 2 forests, and lower $\mathrm{Mn}$ concentrations in the order: $\mathrm{M} 6<\mathrm{M} 35<$ M8 (Table 1). Only vertical profiles of $\mathrm{NO}_{2}{ }^{-}+\mathrm{NO}_{3}{ }^{-}$ (Fig. 5) showed a clear depth-related pattern, with a decline in concentrations with increasing sediment depth at all 3 sites (overlying water-column concentrations of $\mathrm{NO}_{2}{ }^{-}+\mathrm{NO}_{3}{ }^{-}$are arrowed in Fig. 5). $\mathrm{NO}_{2}{ }^{-}+\mathrm{NO}_{3}{ }^{-}$concentrations were detectable at all depths, ranging from 0.1 to $0.9 \mu \mathrm{M}$ below $20 \mathrm{~cm}$ at all 3 forests (Fig. 5). Differences over the entire depth horizon were not significant among the 3 sites, although there were significant differences among sites at a depth of 4 to $6 \mathrm{~cm}$ (Fig. 5).

Vertical profiles of solid-phase elements exhibited a similar lack of depth-related patterns and differences among the forests (Table 2). The only station difference was lower Mn concentrations at Stn M35 than at the other 2 sites (Table 2).

Pyrite sulfur constituted a major fraction of the total solid-phase $\mathrm{S}$ pool at each site (Fig. 6). On average, pyrite $\mathrm{S}$ constituted 92,80 , and $62 \%$ of the total S pools

Table 1. Rhizophora apiculata forests. Mean ( 1 1 SE) porewater concentrations of ammonium, phosphate, dissolved organic carbon, total iron, and total manganese in sediments of all 3 forests, October 1996 . Values $(\mu M)$ are means of $2 \mathrm{~cm}$ interval subsamples of triplicate cores to a depth of $40 \mathrm{~cm}$

\begin{tabular}{|lccc|}
\hline Solute & M6 & M8 & M35 \\
\hline $\mathrm{NH}_{4}{ }^{+}$ & $37.1 \pm 16.5$ & $15.9 \pm 5.1$ & $36.7 \pm 14.8$ \\
$\mathrm{PO}_{4}{ }^{3-}$ & $0.8 \pm 0.4$ & $0.6 \pm 0.3$ & $0.7 \pm 0.3$ \\
$\mathrm{DOC}$ & $23300 \pm 2200$ & $31400 \pm 5100$ & $34700 \pm 7000$ \\
$\mathrm{Fe}$ & $16 \pm 7$ & $45 \pm 11$ & $44 \pm 18$ \\
$\mathrm{Mn}$ & $9 \pm 1$ & $66 \pm 9$ & $28 \pm 3$ \\
\hline
\end{tabular}

Table 2. Rhizophora apiculata forests. Mean ( $\pm 1 \mathrm{SE}$ ) concentrations of total organic carbon, total nitrogen, molar $\mathrm{C}: \mathrm{N}$ ratio, total phosphorus, and total manganese in sediments of all 3 forests, October 1996. Values (percentages sediment dry wt) are means of $2 \mathrm{~cm}$ interval subsamples of triplicate cores to a depth of $40 \mathrm{~cm}$

\begin{tabular}{|lccc|}
\hline Element & M6 & M8 & M35 \\
\hline TOC & $4.90 \pm 1.40$ & $3.95 \pm 2.40$ & $6.23 \pm 1.90$ \\
TN & $0.253 \pm 0.05$ & $0.256 \pm 0.10$ & $0.382 \pm 0.11$ \\
C/N & 22.6 & 18.0 & 19.0 \\
TP & $0.044 \pm 0.016$ & $0.070 \pm 0.026$ & $0.037 \pm 0.107$ \\
Mn & $0.025 \pm 0.011$ & $0.039 \pm 0.023$ & $0.016 \pm 0.003$ \\
\hline
\end{tabular}


at Stns M6, M8 and M35, respectively. The percentage contribution of pyrite Fe to the total Fe pool (Fig. 6) was much less, averaging 19,10 and $24 \%$ at Stns M6, M8 and M35, respectively. Only at Stn M6 was there a significant increase (for pyrite $\mathrm{S}$ and $\mathrm{Fe}$, total S) or decrease (for total $\mathrm{Fe}$ ) with increasing sediment depth (Fig. 6).

\section{Gas and solute fluxes}

Gas fluxes across the sediment-air interface (Table 3) were very variable among replicate chambers and among sites with time. In May 1997, $\mathrm{CO}_{2(\mathrm{gl})}$ fluxes were slowest at Stn M8 and equivalent at the other 2 sites. In November 1997, rates were in the order: M35 > M6 > M8 (Table 3). Seasonal differences were significant only at $\mathrm{Stn}$ M8. In November 1997, fluxes of $\mathrm{SCO}_{2}$ across the sediment-water interface in flooded cores were not significantly different from $\mathrm{CO}_{2}$ gas fluxes at Stn $\mathrm{M} 6 ; \Sigma \mathrm{CO}_{2}$ fluxes were greater than $\mathrm{CO}_{2}$ gas fluxes at Stn $\mathrm{M} 8$, but less at Stn M35 (Table 3). No methane flux was detected from exposed sediments at any of the 3 forests.

Oxygen fluxes (Table 3) were not significantly different between sites in May and November 1997. However, $\mathrm{O}_{2}$ flux rates were significantly slower at Stns M6 and M35 in November 1997 compared to flux rates measured at each site in May 1997.

Fluxes of dissolved nutrients and metals across the sediment-water interface in flooded cores (Table 4) were very variable both between replicate chambers and between forests with season, masking clear and consistent differences among forests. On average, there was less flux at Stn M6 than at Stns M8 and M35 (Table 4), and more nutrient and metal flux in November 1997 than in May 1997. Most fluxes were not significant over the $3 \mathrm{~h}$ incubation period.
Table 3. Rhizophora apiculata forests. Mean ( \pm 1 SE) fluxes of $\mathrm{CO}_{2(\mathrm{~g})}$ and $\mathrm{O}_{2(\mathrm{gl})}$ across sediment-air interface (exposed sediments), and $\Sigma \mathrm{CO}_{2}$ across sediment-water interface (flooded sediments) in opaque-glass chambers. Gas measurements made in May and November 1997, solute flux measured only in November 1997. Values are mmol m $\mathrm{m}^{-2} \mathrm{~d}^{-1} \mathrm{NA}$ : no measurements

\begin{tabular}{|c|c|c|c|}
\hline & $\mathrm{CO}_{2(g)}$ & $\Sigma \mathrm{CO}_{2}$ & $\mathrm{O}_{2 i g i}$ \\
\hline \multicolumn{4}{|l|}{ M6 } \\
\hline May 1997 & $59.1 \pm 1.0$ & & $140.5 \pm 56.6$ \\
\hline Nov 1997 & $50.8 \pm 3.4$ & $34.5 \pm 28.8$ & $19.2 \pm 6.7$ \\
\hline \multicolumn{4}{|l|}{ M8 } \\
\hline May 1997 & $35.9 \pm 3.0$ & & $67.7 \pm 13.8$ \\
\hline Nov 1997 & $1.7 \pm 0.6$ & $13.7 \pm 5.2$ & $\mathrm{NA}$ \\
\hline \multicolumn{4}{|l|}{ M35 } \\
\hline May 1997 & $52.5 \pm 24.5$ & & $55.0 \pm 18.0$ \\
\hline Nov 1997 & $80.4 \pm 15.7$ & $28.3 \pm 8.3$ & $13.0 \pm 1.7$ \\
\hline
\end{tabular}

Table 4. Rhizophora apiculata forests. Mean ( $\pm 1 \mathrm{SE}$ ) fluxes of dissolved nutrients and metals across sediment-water interface (flooded sediments) in glass chambers in May and November 1997 . Values are $\mu \mathrm{mol} \mathrm{m} \mathrm{m}^{-2} \mathrm{~d}^{-1} \cdot$ No significant flux

\begin{tabular}{|c|c|c|c|c|c|c|}
\hline \multirow[t]{2}{*}{ Solute } & \multicolumn{2}{|c|}{ M6 } & \multicolumn{2}{|c|}{ M8 } & \multicolumn{2}{|c|}{ M35 } \\
\hline & May & Nov & May & Nov & May & Nov \\
\hline $\mathrm{DOC}(\mathrm{mmol})$ & $\cdot$ & • & $85.8 \pm 11.0$ & $16.4 \pm 3.1$ & - & $71.2 \pm 25.9$ \\
\hline $\mathrm{NH}_{4}{ }^{+}$ & $\cdot$ & $\cdot$ & - & - & $-8710 \pm 3900$ & $32740 \pm 15280$ \\
\hline $\mathrm{NO}_{2}^{-}+\mathrm{NO}_{3}^{-}$ & $-5090 \pm 750$ & $\cdot$ & $\cdot$ & $-6030 \pm 1100$ & $-1075 \pm 285$ & $-2680 \pm 330$ \\
\hline DON & $\cdot$ & - & - & $\cdot$ & $\cdot$ & $19600 \pm 6750$ \\
\hline $\mathrm{PO}_{4}^{3-}$ & $\cdot$ & $\cdot$ & $\cdot$ & $1320 \pm 405$ & $\cdot$ & - \\
\hline DOP & $\cdot$ & $\cdot$ & $\cdot$ & $1360 \pm 490$ & $\cdot$ & $\cdot$ \\
\hline $\mathrm{Fe}$ & . & $1800 \pm 800$ & - & $4490 \pm 850$ & - & $15350 \pm 2520$ \\
\hline $\mathrm{Mn}$ & $-1720 \pm 140$ & $-5170 \pm 2820$ & $\cdot$ & $6700 \pm 1120$ & $\cdot$ & \\
\hline
\end{tabular}


Solid-phase Sulfur ( $\mathrm{mg} \mathrm{g}^{-1}$ sediment DW)

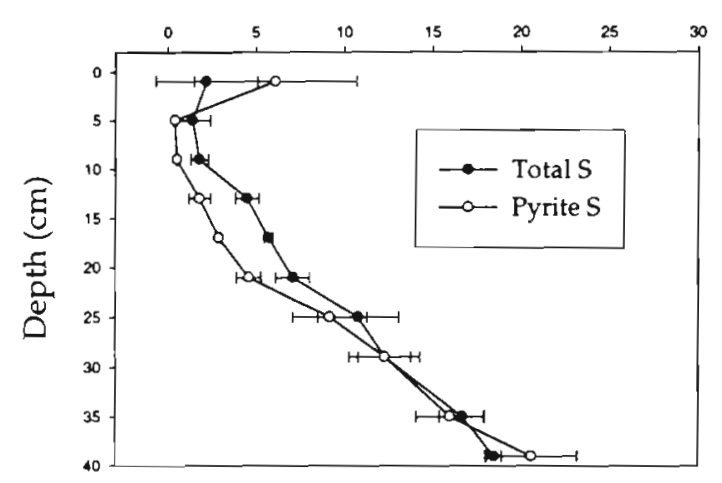

Solid-phase Sulfur ( $\mathrm{mg} \mathrm{g}^{-1}$ sediment DW)

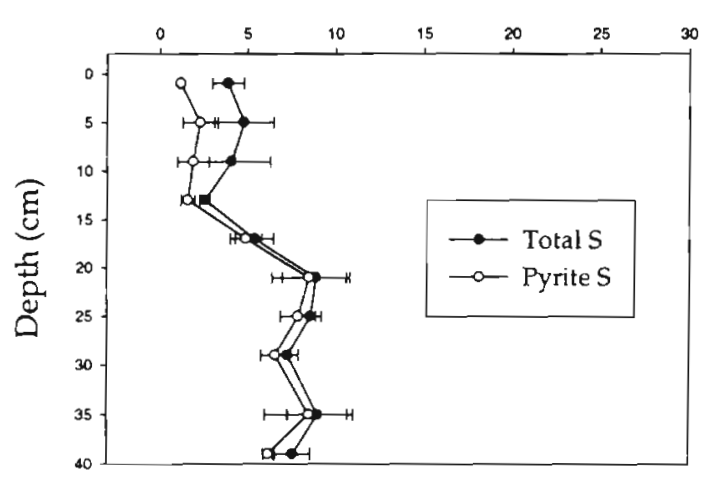

\section{Station M6}

Solid-phase Iron ( $\mathrm{mg} \mathrm{g}^{-1}$ sediment DW)

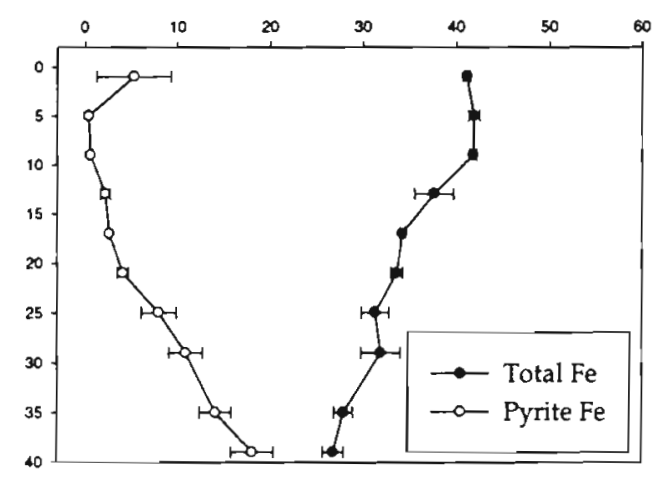

\section{Station M8}

Solid-phase Iron ( $\mathrm{mg} \mathrm{g}^{-1}$ sediment DW)

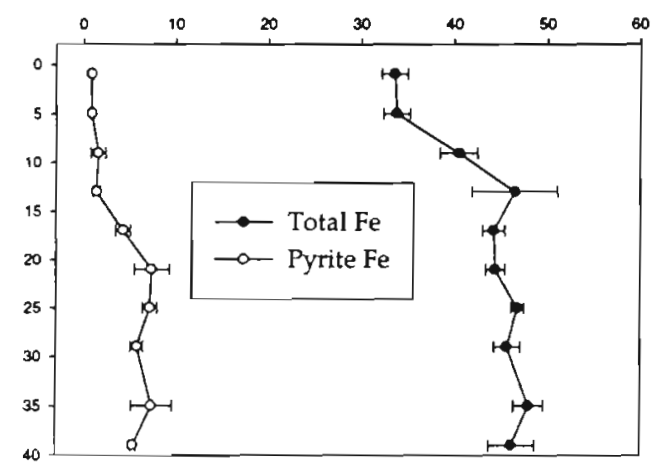

\section{Station M35}

Solid-phase Sulfur ( $\mathrm{mg} \mathrm{g}^{-1}$ sediment DW)

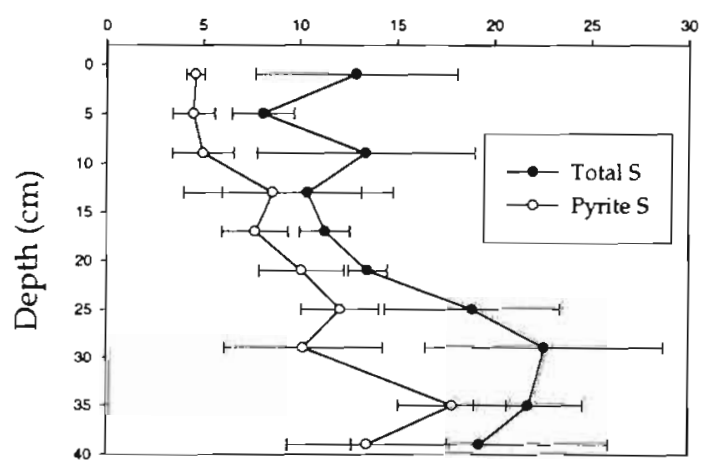

Solid-phase Iron $\left(\mathrm{mg} \mathrm{g}^{-1}\right.$ sediment DW)

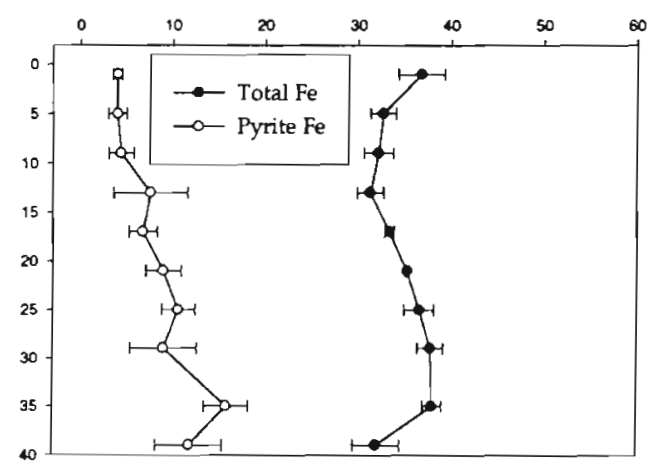

Fig. 6. Rhizophora apiculata forests. Vertical profiles (means $\pm 1 \mathrm{SE}$ ) of solid-phase total sulfur and pyrite sulfur and total iron and pyrite iron at Stns M6, M8, and M35, October 1996. DW = dry weight

\section{Iron and manganese reduction}

Core incubations resulted in significant increases in dissolved $\mathrm{Mn}$ in pore water for all 3 forests (Fig. 7). Summing depths, rates of manganese reduction were slowest at Stn M6 $\left(1.0 \pm 0.6 \mathrm{mmol} \mathrm{Mn} \mathrm{m}^{-2} \mathrm{~d}^{-1}\right)$ and equivalent at
Stns M8 $\left(2.8 \pm 1.2 \mathrm{mmol} \mathrm{Mn} \mathrm{m} \mathrm{m}^{-2} \mathrm{~d}^{-1}\right)$ and M35 $(2.4 \pm$ $0.7 \mathrm{mmol} \mathrm{Mn} \mathrm{m} \mathrm{m}^{-2} \mathrm{~d}^{-1}$ ). Rates of $\mathrm{Mn}$ reduction were generally greater in sediments over the 0 to $12 \mathrm{~cm}$ horizon than in the deeper sediment layers at each site (Fig. 7), although depth-related differences were not significant due to large between-core variability. 


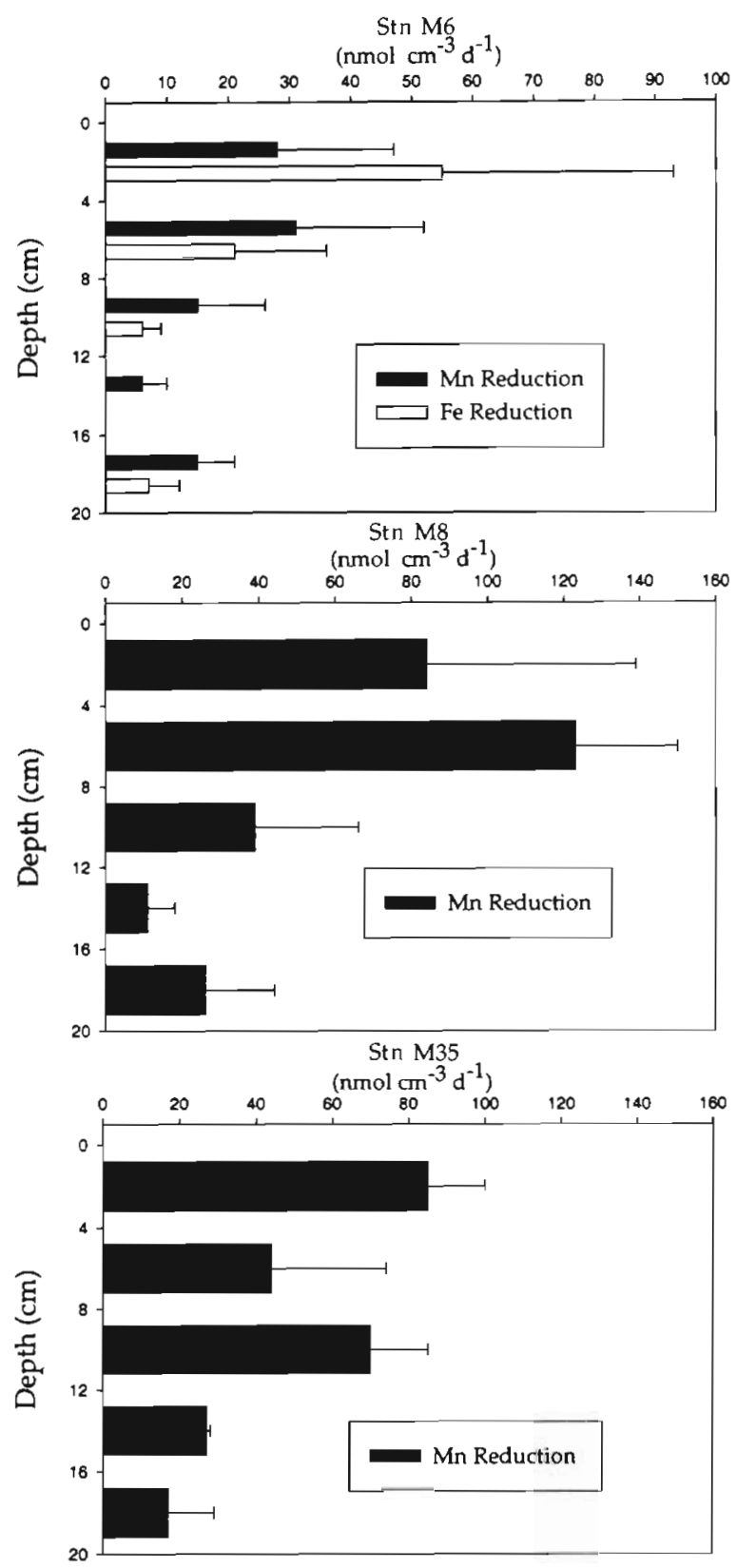

Fig. 7. Rhizophora apiculata forests. Rates (means $+1 \mathrm{SE}$ ) of metal reduction at Stns M6, M8, and M35, November 1997, at $4 \mathrm{~cm}$ intervals to sediment depth of $20 \mathrm{~cm}$. Note lack of significant iron reduction at latter 2 sites
Iron reduction was detected only at Stn M6 (Fig. 7) where the fastest rates of reduction were measured in surface (0 to 4 and 4 to $8 \mathrm{~cm}$ depth) layers. Summing depths, the rate of iron reduction was $0.9 \pm 0.6 \mathrm{mmol}$ Fe $\mathrm{m}^{-2} \mathrm{~d}^{-1}$.

\section{Sulfate reduction}

Rates of sulfate reduction were slow, ranging from 0.2 $\pm 0.1 \mathrm{mmol} \mathrm{S} \mathrm{m}^{-2} \mathrm{~d}^{-1}$ at Stn M8 in May 1997 to $13.0 \pm$ $5.7 \mathrm{mmol} \mathrm{S} \mathrm{m}^{-2} \mathrm{~d}^{-1}$ at Stn M35 in October 1996 (Table 5). Stn M35 exhibited the highest rates in October 1996, but in May 1997 sulfate reduction rates were equivalent between Stns M6 and M35. In October 1996, rates of sulfate reduction were slowest at Stn M6. Seasonally, rates of sulfate reduction were higher in October 1996 than in May 1997 at Stns M8 and M35; there was no seasonality at Stn M6 (Table 5). Most ${ }^{35} \mathrm{~S}$ was incorporated into the CRS rather than into the AVS fraction $(\leq 8 \%)$ at all 3 forests (Table 5 ). All 3 forests exhibited different depth-related patterns in sulfate reduction. At Stn $M 6$, rates generally increased with increasing sediment depth, particularly in May 1997 (Fig. 8). At Stn M8, rates were faster in sediments over the 0 to $12 \mathrm{~cm}$ horizon in October 1996, but the opposite pattern was exhibited in May 1997 (Fig. 9), with little or no measurable sulfate reduction in the upper $7 \mathrm{~cm}$. At Stn M35, the depth pattern was not clear in October 1996, with highest rates over the 8 to $12 \mathrm{~cm}$ interval (Fig. 10), but rates increased with increasing depth in May 1997.

\section{Denitrification and nitrogen fixation}

Denitrification was detected only at Stn M35 (mean \pm $1 \mathrm{SE}: 2.2 \pm 0.5 \mathrm{mmol} \mathrm{N}_{2} \mathrm{~m}^{-2} \mathrm{~d}^{-1}$ ) in November $1997 . \mathrm{N}_{2}$ fluxes measured in May 1997 between control and experimental chambers were not significantly different at Stns M6 and M8.

Rates of nitrogen fixation measured in November 1997 were greater at Stn M8 (mean \pm 1 SE: $1425 \pm$ $468 \mu \mathrm{mol} \mathrm{N} \mathrm{m}^{-2} \mathrm{~d}^{-1}$ ) than at Stns M6 (mean \pm 1 SE: 245 $\pm 127 \mu \mathrm{mol} \mathrm{N} \mathrm{m}^{-2} \mathrm{~d}^{-1}$ ) and M35 (mean \pm 1 SE: $444 \pm$

Table 5. Rhizophora apiculata forests. Total rates (means $\pm 1 \mathrm{SE}$ ) of sulfate reduction in sediments of all 3 forests in October 1996 and May 1997. Values (mmol S m${ }^{-2} \mathrm{~d}^{-1}$ ) are means over entire depth interval. Values in parentheses: percentage of ${ }^{35} \mathrm{~S}$ recovered as acid-volatile sulfide $(\%$ AVS $)$

\begin{tabular}{|c|c|c|c|c|c|c|}
\hline Date & $\begin{array}{c}\text { M6 } \\
\text { Depth }(\mathrm{cm})\end{array}$ & Rate & $\begin{array}{c}\text { M8 } \\
\text { Depth }(\mathrm{cm})\end{array}$ & Rate & $\begin{array}{c}\text { M35 } \\
\text { Depth }(\mathrm{cm})\end{array}$ & Rate \\
\hline Oct 1996 & 34 & $1.1 \pm 0.1(1 \%)$ & 40 & $4.6 \pm 1.3(7 \%)$ & 40 & $13.0 \pm 5.7(6 \%)$ \\
\hline May 1997 & 36 & $1.2 \pm 0.6(3 \%)$ & 32 & $0.2 \pm 0.1(8 \%)$ & 38 & $1.4 \pm 0.7(5 \%)$ \\
\hline
\end{tabular}



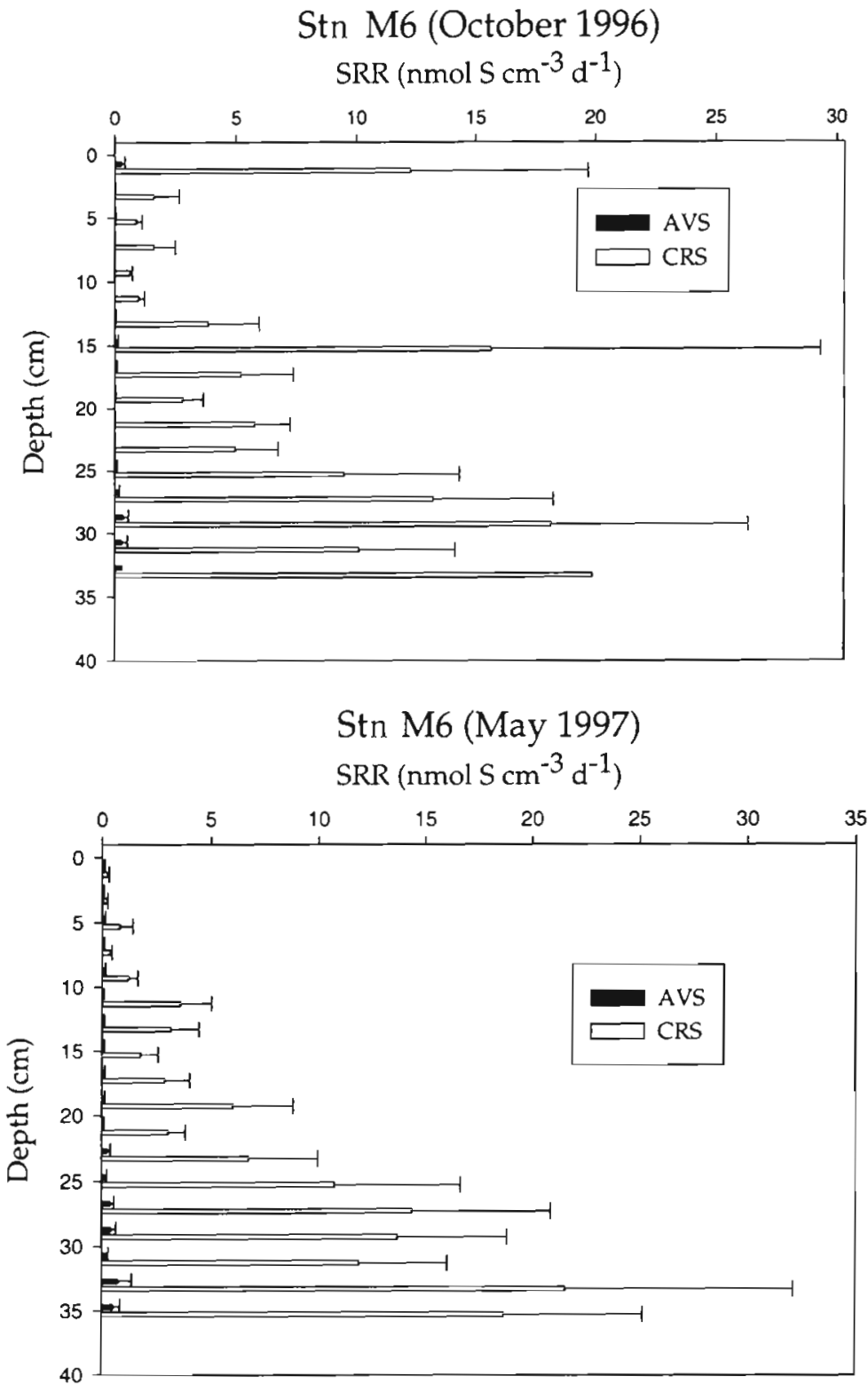

Fig. 8. Rhizophora apiculata forests. Vertical changes (means + 1 SE) in rates of sulfate reduction (SRR) recovered in acid-volatile sulfide (AVS) and chromium-reducible sulfur (CRS) fractions in sediments of Stn M6 in October 1996 and May 1997

$92 \mu \mathrm{mol} \mathrm{N}_{2} \mathrm{~m}^{-2} \mathrm{~d}^{-1}$ ), where rates of $\mathrm{N}_{2}$ fixation were equivalent.

\section{DISCUSSION}

A preliminary budget of the contribution of the different metabolic pathways to total carbon mineralization (Fig. 11) indicates that decomposition of sediment organic matter in all 3 Rhizophora apiculata forests despite differences in forest age and slower rates of total carbon oxidation in the 8 yr old forest was dominated by aerobic respiration. Oxic respiration cannot be directly measured in sediments. Aerobic metabolism in each forest was therefore estimated as the difference between rates of total carbon oxidation minus the sum of the other individual metabolic pathways, yielding average rates of 45.1, 10.9, and $33.8 \mathrm{mmol} \mathrm{C} \mathrm{m} \mathrm{C}^{-1}$ at Stns M6, M8, and M35, respectively.

Sulfate and metal reduction appeared to be minor pathways, and there was no evidence for methanogenesis. This budget is a first-order estimate. It does not reflect temporal and spatial variability of the various measurements (some of which were taken at different times) or some methodological limitations (see below). It is likely, however, that our measurements incorporate most of the benthic microbial activity in these forests, as sediments $>40 \mathrm{~cm}$ depth consisted of very hard grey clay with minimal organic matter. Our findings are in agreement with similar measurements made in high intertidal forests in southern Thailand, where sulfate reduction accounted for only $11 \%$ of total carbon mineralization (Kristensen et al. 1995), and in high intertidal forests in Jamaica (Nedwell et al. 1994), where oxic respiration ( $78 \mathrm{mmol} \mathrm{C} \mathrm{m} \mathrm{m}^{-2} \mathrm{~d}^{-1}$ ) was greater than rates of sulfate reduction $(23 \mathrm{mmol} C$ $m^{-2} d^{-1}$ ).

Measurements of other sediment parameters point to the dominance of aerobic respiration: (1) The redox measurements were mostly positive (Fig. 3), especially in the 8 and $35 \mathrm{yr}$ old plantations. (2) There was no evidence of free sulfides or methane in the pore water; indeed, concentrations of reduced solutes $\left(\mathrm{NH}_{4}{ }^{+}\right)$were low compared with concentrations measured in similar Rhizophora spp. forests (Boto 1992, Kristensen et al. 1995, 1998, Alongi et al. 1998). This condition may reflect oxidation of ammonium or uptake by the trees, or both processes. (3) Pore-water concentrations of $\mathrm{NO}_{2}^{-}+\mathrm{NO}_{3}^{-}$were highest over the upper $20 \mathrm{~cm}$, but measurable to $40 \mathrm{~cm}$. The presence of nitrate deep into the forest floor is probably due to several factors, including nitrification in rhizomes and the oxidative impacts of intense bioturbation and desiccation (Kristensen et al. 1998). (4) There was excess sulfate in the pore water relative to chloride concentrations, despite the fact that $R$. apiculata trees actively exclude $\mathrm{Cl}^{-}$ions (Ball 1988). The high sulfate/chloride ratio likely reflects oxidation of 
sulfides produced by sulfate reducers. (5) $\mathrm{pH}$ was low. This may reflect production of $\mathrm{H}_{2} \mathrm{CO}_{3}$ from aerobic breakdown of organic matter. (6) Only a moderate (10 to $24 \%$ ) proportion of solid-phase iron was bound as pyrite, implying that most Fe was present as iron oxyhydroxides (Rickard et al. 1995).

The lack of frequent tidal inundation and physiological activities of the trees may explain the dominance of aerobic respiration and the acidity of these sediments. These plantations are located in the high intertidal and are inundated for a few hours only 3 to $5 \mathrm{~d} \mathrm{mo}^{-1}$. During prolonged periods of air exposure, the sediments become desiccated (water content ranged from 10 to $15 \%$ ). These sediments (consisting of fine and coarse roots and rhizomes, and pockmarked with numerous crab burrows) drain nearly dry, exposing surface and subsurface sediments lining burrows, fissures, cracks and surrounding roots to the atmosphere. In mangrove forests in Pakistan, Kristensen et al. (1992) observed that during desiccation total microbial activity is reduced. They also measured higher rates of oxygen consumption in exposed sediments than in submerged sediments ${ }_{i}$ they attributed this to greater aerobic activity and less diffusive boundary-layer problems in air compared to water. These cycles of flooding and emergence may therefore result in temporal and spatial oscillations in redox status, as suggested by Aller (1994) for bioturbated sediments and terrestrial rhizospheres.

Aerobic metabolism may have been enhanced by the presence of crabs. Ridd (1996) recently found crab burrows to be responsible for the enhanced transport of tidal water and pore water (and presumably re-oxidation) in mixed Rhizophora spp. forests in northern Australia. Also, some benthic organisms store air in their burrows (Ishimatsu et al. 1998). Such may be the case in the Mekong plantations, where we observed numerous biogenic structures.

The physiological activities of the trees (root respiration, etc.) may also alter sediment conditions. As noted by Middelburg et al. (1996) for sediments in mangrove forests in Kenya, mangroves can affect acid-base and redox condition in several ways: (1) via translocation of oxygen to their roots and release to sediments; (2) via uptake of $\mathrm{NH}_{4}^{+}$by the trees leading to $\mathrm{H}^{+}$release; and/or (3) via $\mathrm{CO}_{2}$ respired by the roots, resulting in lower $\mathrm{pH}$. Oxidation of reduced compounds would also be likely to induce acidification, particularly in

\section{Stn M8 (October 1996)}

$\operatorname{SRR}\left(\mathrm{nmol} \mathrm{S} \mathrm{cm} \mathrm{cm}^{-3} \mathrm{~d}^{-1}\right.$ )

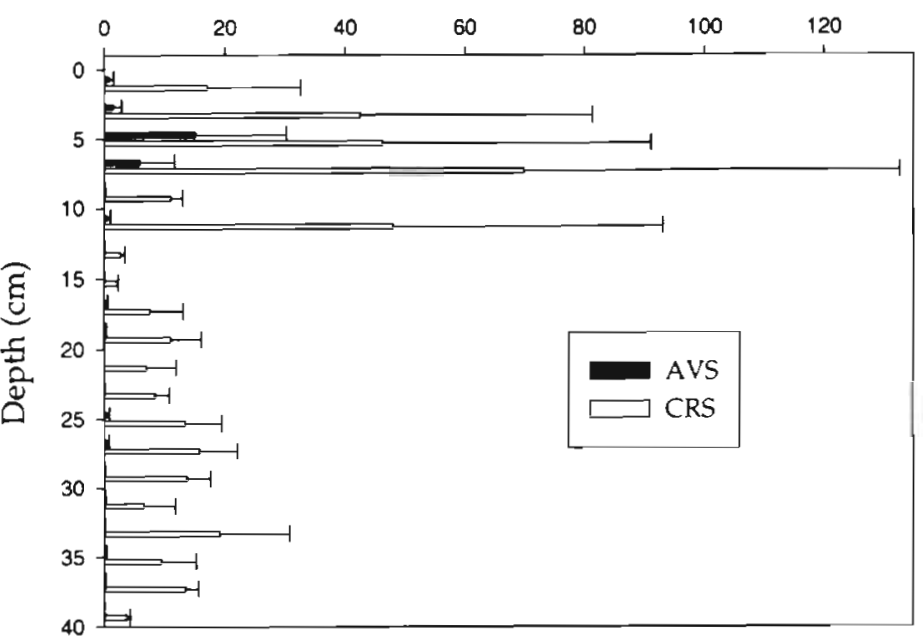

Stn M8 (May 1997)

SRR ( $\left.\mathrm{nmol} \mathrm{S} \mathrm{cm}{ }^{-3} \mathrm{~d}^{-1}\right)$

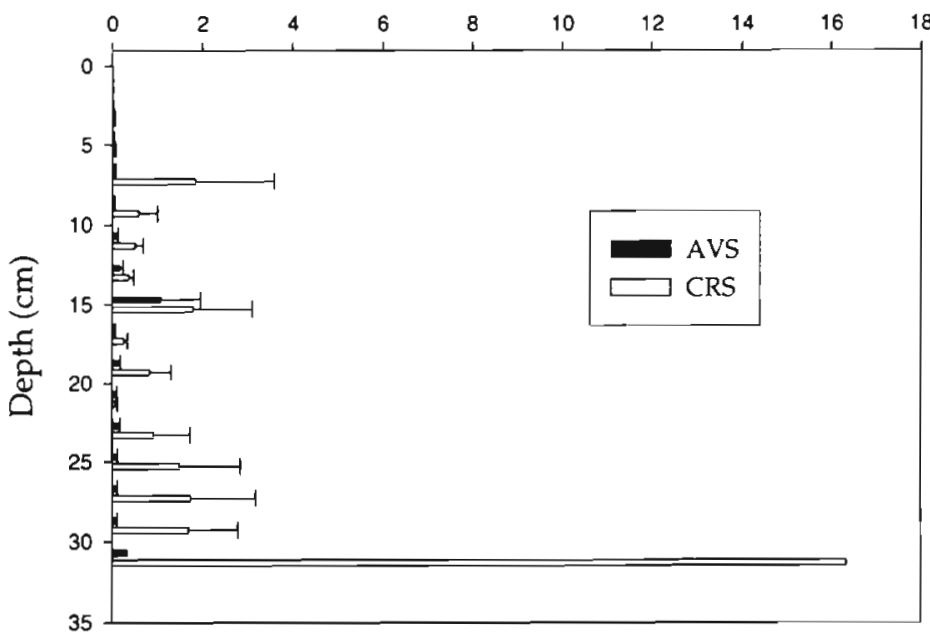

Fig. 9. Rhizophora apiculata forests. Vertical changes (means + $1 \mathrm{SE}$ ) in rates of sulfate reduction recovered in acid-volatile sulfide (AVS) and chromium-reducible sulfur (CRS) fractions in sediments of Stn M8 in October 1996 and May 1997; note differences in scales

sediments with limited buffering capacity. Aerobic respiration and oxidation of $\mathrm{NH}_{4}, \mathrm{H}_{2} \mathrm{~S}$, FeS and $\mathrm{FeS}_{2}$ would result in the production of $\mathrm{H}_{2} \mathrm{CO}_{3}, \mathrm{HNO}_{3}$, and $\mathrm{H}_{2} \mathrm{SO}_{4}$. Mangroves may also release organic acids into the sediment (Ball 1988). Various studies have shown that mangroves can modify sediment $\mathrm{pH}$ and redox conditions (Boto 1992, Kristensen et al. 1995, Alongi 2000).

The lowest $\mathrm{pH}$ values were recorded for the $8 \mathrm{yr}$ old forest. It is very likely that these trees were negatively affected by leaching from acid-sulfate soils on levee banks of the adjacent shrimp pond (Alongi et al. 

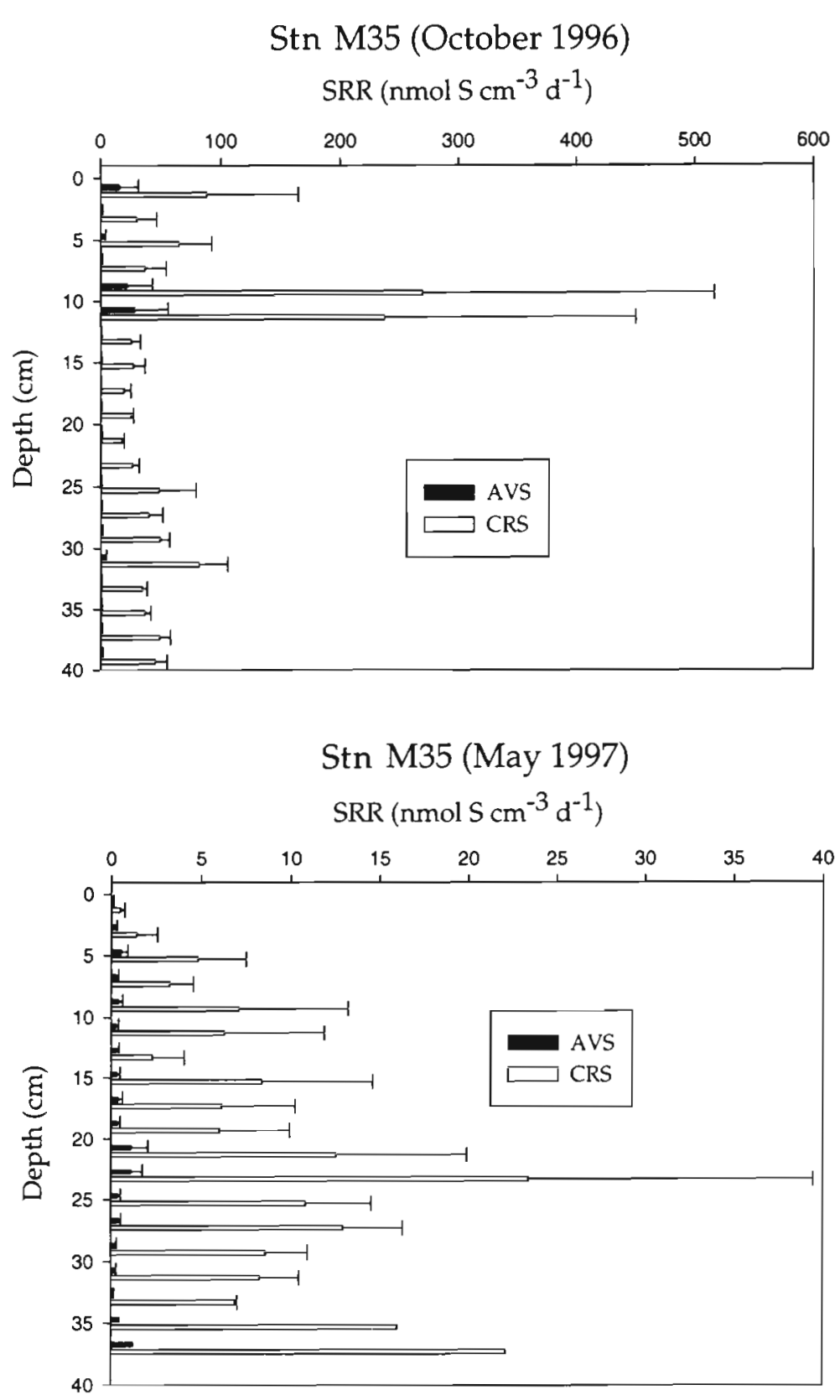

Fig. 10. Rhizophora apiculata forests. Vertical changes (means + $1 \mathrm{SE}$ ) in rates of sulfate reduction ( $\mathrm{nmol} \mathrm{cm}^{-3} \mathrm{~d}^{-1}$ ) recovered in acid-volatile sulfide (AVS) and chromium-reducible sulfur (CRS) fractions in sediments of Stn M35 in October 1996 and May 1997; note differences in scales

The influence of forest age on sediment biogeochemical processes appeared to be minimal, given the lack of significant difference in rates of total carbon oxidation between the youngest and the oldest forests and the dominance of oxic decomposition in all 3 forests. The most obvious influences were the greater proportion of aerobic respiration, and proportionally less sulfate and manganese reduction, in the 6 yr old forest compared with the 2 older stands. The magnitude of the individual decomposition pathways in these Vietnamese forests is very similar to our measurements in Western Australian mangroves (Alongi 2000), where oxic respiration accounted for 58 to $80 \%$ of total carbon mineralization, with sulfate reduction being the secondmost important process ( 15 to $43 \%$ ).

Slow rates of iron and manganese reduction may be caused by several factors, including low $\mathrm{pH}$ and mostly positive redox status, as well as methodological difficulties. It is possible that metal reduction was occurring at sediment depths $>20 \mathrm{~cm}$ (the depth limit of our measurements). Also, the coreincubation method does not account for possible adsorption and chelation reactions that would cause $\mathrm{Fe}$ and $\mathrm{Mn}$ reduction rates to be underestimated. There may have been stimulation of microbial reduction caused by sediment mixing, although chemical reduction, if occurring, would not be distinguishable from microbial reduction of $\mathrm{Fe}$ and Mn oxides. Nevertheless, even if rates of $\mathrm{Fe}$ and $\mathrm{Mn}$ reduction were underestimated by $100 \%$, both processes would still constitute minor, and at best, moderate carbon-oxidation pathways.

Rates of total carbon mineralization (grand means of gaseous and dissolved $\mathrm{CO}_{2}$ fluxes $=17.1$ to $53.7 \mathrm{mmol} \mathrm{C} \mathrm{m}^{-2} \mathrm{~d}^{-1}$; Fig. 11) and rates of sulfate reduction were equivalent to rates measured in other high-intertidal mangrove forests (Kristensen et al. 1992, 1995, 1998, Nedwell et al. 1994, Alongi et

$1999 b)$. In soils from this pond pyrite was very abundant (up to $5.6 \%$ sediment dry wt). It is possible that this pyrite was being oxidized and transported during feavy monsoonal rains. Pyrite within the mangrove sediments comprised a much lower percentage of sediment dry wt $(1.4 \%$ at $\operatorname{Stn} M 6,0.9 \%$ at $\operatorname{Stn} \mathrm{M} 8,1.6 \%$ at Stn M35) than within the pond soils, although 62 to $92 \%$ of the total solid-phase $S$ pool in the mangrove sediments was bound in pyrite. al. 1998, Alongi 2000). Rates of total mineralization, oxygen flux, and sulfate reduction varied greatly between sampling periods, although there were no obvious ecological or climatological changes over time. It is likely that these seasonal differences reflect spatial variability as much as true temporal patchiness.

The rates of oxygen consumption were, on average, either equivalent to or more rapid than rates of either 


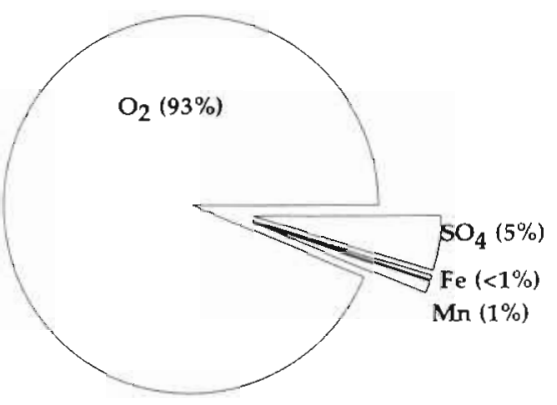

M6 $\left(\mathrm{T}_{\mathrm{cox}}=48.1\right)$

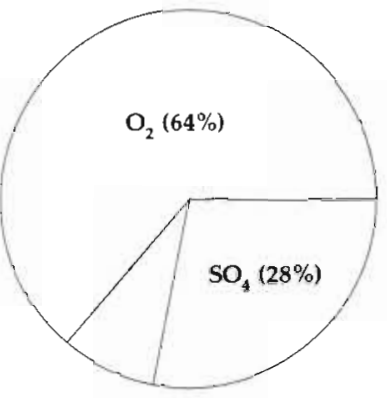

Mn (8\%)

$\operatorname{M8}\left(\mathrm{T}_{\mathrm{COX}}=17.1\right)$

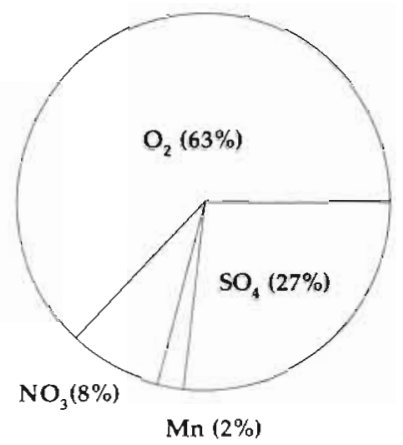

$\mathrm{M} 35\left(\mathrm{~T}_{\mathrm{COX}}=53.7\right)$

Fig. 11. Rhizophora apiculata forests. Estimates of mean percent contribution of individual metabolic pathways to average total carbon oxidation ( $\mathrm{T}_{\mathrm{COx}}$, in mmol $\mathrm{C} \mathrm{m}^{-2} \mathrm{~d}^{-1}$ ) at Stns M6, M8, and M35. Rates of oxic respiration for each site estimated as difference between $I_{C o x}$ and sum of rates of metal reduction, sulfate reduction and denitrification (there was no methanogenesis) Each metabolic pathway was converted to carbon equivalents using diagenetic equations in Fig. 1.1 of Alongi (1998)

$\mathrm{CO}_{2}$ gas or $\sum \mathrm{CO}_{2}$ production (Table 3). Estimated rates of aerobic respiration (Fig. 11) averaged 45.1, 10.9 and $33.8 \mathrm{mmol} \mathrm{C} \mathrm{m} \mathrm{m}^{-2} \mathrm{~d}^{-1}$ at Stn.s M6, M8, and M35, respectively. These values were less than the measured rates of total oxygen production. At Stns M6 and M8, the discrepancy equates to 34.8 and $56.8 \mathrm{mmol} \mathrm{C} \mathrm{m}^{-2} \mathrm{~d}^{-1}$. respectively, implying that $\sim 44$ and $-84 \%$ of total oxygen uptake in sediments of the 6 and 8 yr old forests was by chemical oxidation. In the $35 \mathrm{yr}$ old forest, the discrepancy was minimal. These are crude estimates, as absolute rates would depend upon the accuracy of measurements of the other metabolic pathways and total carbon oxidation.

Total carbon oxidation in the exposed sediments, estimated by measuring rates of gaseous $\mathrm{CO}_{2}$ flux, may be slightly underestimated considering that we used a closed system to measure gas release. Normally, $\mathrm{CO}_{2}$ flux must be measured in an open system in order to maintain steady-state between gaseous and aqueous phases; a closed system would accumulate and subsequently lose gaseous $\mathrm{CO}_{2}$ to the pore water $\mathrm{HCO}_{3}{ }^{-}$ and $\mathrm{CO}_{3}{ }^{2-}$ phases. Such losses are probably minor in habitats where sediments are exposed to the atmosphere for long time periods, such as is the case for the Mekong mangroves. Water content of the exposed sediments was low (10 to $15 \%$ ), thereby limiting the amount of gaseous $\mathrm{CO}_{2}$ equilibrating with the aqueous phase. If the gaseous $\mathrm{CO}_{2}$ rates were seriously underestimated, rates of $\sum \mathrm{CO}_{2}$ flux would have been significantly greater than the gas fluxes at all 3 sites. Such was the case only at Stn M8 (Table 3). At the other 2 forests, rates of gaseous $\mathrm{CO}_{2}$ flux were either equal to (Stn M6) or greater than (Stn M35) rates of $\Sigma \mathrm{CO}_{2}$ flux. It is probable that microbial activity was slower during exposure and desiccation. Recent studies have demonstrated clear changes in pore-water chemistry and physicochemical conditions as a result of tidal drainage and flooding cycles on intertidal mudflats and in other mangrove forests (Kerner \& Wallman 1992, Alongi et al. 1999a, Cabrita et al. 1999, Alongi 2000). Such changes are likely to be magnified in intertidal habitats inundated by large tides and/or located at higher tidal elevation. In mangrove forests, tidal pumping and drainage may be further accentuated by the numerous animal burrows and dense mats of fine and coarse roots

Rates of total carbon oxidation and sulfate reduction were slow compared to those in salt marshes and seagrass beds (Howarth 1993, Alongi 1998). The slow rates of sulfate reduction, particularly in surface sediments, may reflect oxidation of labelled sulfides produced during the core incubations, although this may have been limited by the short ( 4 to $6 \mathrm{~h}$ ) incubation times. We did not evaluate time-course uptake of ${ }^{35} \mathrm{SO}_{4}$, although Nedwell et al. (1994) observed linear uptake of ${ }^{35} \mathrm{SO}_{4}$ for up to $7-8 \mathrm{~h}$ in Jamaican mangrove sediments with higher rates of sulfate reduction activity.

The higher rates of net primary production and slower rates of benthic mineralization in mangrove forests compared with salt marshes (Howarth 1993, Alongi 1998) suggests that carbon, and presumably other nutrient elements, are more efficiently conserved or immobilized within mangrove forests. The ratio of sediment respiration to forest NPP $\left(\mathrm{R}_{\text {hetero }} / \mathrm{NPP}\right)$ for the 6 and 35 yr old forests (there are no NPP data for Stn $\mathrm{M} 8$ ) is $18 \%$ for Stn M6 and $28 \%$ for Stn M35. These compare with $\mathrm{R}_{\text {heter }} / \mathrm{NPP}$ ratios for the mangroves of Western Australia of 8 to $10 \%$ (Alongi 2000), for north Queensland mangroves of $9 \%$ (see Table 3.8 in Alongi 1998) and for the Rookery Bay mangroves in Flonida of $18 \%$ (Table 3.8 in Alongi 1998). In American salt 
marshes, the $\mathrm{R}_{\text {hetero }} / \mathrm{NPP}$ ratios are considerably greater, ranging from 56 to $82 \%$ for the Sippewissett marsh in Massachusetts, 44 to $68 \%$ in the Flax Pond marshes of Long Island, $89 \%$ in the Barataria marshes in Louisiana, and $40 \%$ in the marshes of Sapelo Island, Georgia (Table 3.8 in Alongi 1998).

The comparatively slow remineralization of sediment organic matter in mangrove forests implies immobilization with subsequent conservation of essential nutrients. This idea is supported by the lack of measurable denitrification in the 6 and 8 yr old forests, despite the large amounts of nitrate available in the pore water and overlying tidal water. Denitrification was measurable only in the $35 \mathrm{yr}$ old forest, where it constitutes a small but significant fraction $(8 \%)$ of total carbon oxidation (Fig. 11). The greater rate of nitrogen fixation at the $8 \mathrm{yr}$ old forest than at the other sites is more explainable, as cyanobacterial mats were abundant on the sediment surface and highest light penetration was measured under the 8 yr old canopy (Alongi unpubl. data). The rates of nitrogen fixation were rapid compared with those recorded in previous studies of mangrove forests (Alongi et al. 1992), and are at the upper end of the range of $\mathrm{N}_{2}$ fixation rates measured in other marine and estuarine environments (Howarth et al. 1988).

Slow rates of denitrification have been measured in other mangrove forests (Shaiful et al. 1986, Shaiful 1987. Nedwell et al. 1994, Kristensen et al. 1995, 1998, RiveraMonroy \& Twilley 1996). This phenomenon has been explained as a result of either immobilization of inorganic $\mathrm{N}$ or assimilation by mangroves, or a combination of both processes. Regardless of the particular mechanism(s), slow rates of denitrification coupled with rapid rates of nitrogen fixation imply that nitrogen is being gained rather than lost from the system. A complete nitrogen budget for a mixed Rhizophora spp. forest in northern Australia (Fig 3.9 in Alongi 1998) indicates rapid ammonification in the sediment, and uptake of dissolved organic and inorganic $\mathrm{N}$ from overlying tidal water, with $-90 \%$ of the total dissolved $\mathrm{N}$ flux being assimilated by the trees. Nedwell et al. (1994) found that in Jamaican forests, nitrogen fixation rates were too low to balance denitrification losses; rapid ammonium turnover was therefore presumed to supply the nitrogen required for mangrove primary production.

The immobilization/retention of nitrogen in mangrove forests is in agreement with the prediction that there would be no net mineralization of nitrogen or accumulation of microbial biomass from substrates with high C:N ratios (Fenchel et al. 1998). For example, in terrestrial ecosystems, substrate C:N ratios $>30$ result in low microbial assimilation efficiencies, a decrease in mineralization, but an increase in immobilization (Fenchel et al. 1998). Given the high C:N ratios of mangrove organic matter (Alongi 1998), a similar scenario is likely in tropical mangrove forests. Comparison with other forested ecosystems suggests that mangroves behave similarly to other tropical forests with respect to more efficient carbon and nitrogen sequestration and immobilization than their temperate counterparts (Raich \& Nadelhoffer 1989, Raich \& Schlesinger 1992, Dixon et al. 1994).

Acknowledgements. This project was funded by a grant (PN 9412) from the Australian Centre for International Agricultural Research, and by the Australian Institute of Marine Science. We thank the Ministry of Fisheries, Vietnam, the Director and staff of the Research Institute for Aquaculture No. 2 and Tam Giang III for their help, especially Mr Doan Van Tien and Mrs B. G. Huyen. Mr Hoang and Mr Hung are thanked for their hospitality and for permission to sample their ponds. D. Johnston and P. Dixon helped with the fieldwork, C. Payn, $S$. Boyle, O. Dalhaus, and J. WuWon provided laboratory assistance, and B. Smith and B. Clough are thanked for their encouragement and support. B. Clough supplied the primary production data, and D. B. Nedwell reviewed an earlier draft. We thank 3 anonymous reviewers for their helpful comments. This is contribution No. 979 from the Australian Institute of Marine Science.

\section{LITERATURE CITED}

Aller RC (1994) Bioturbation and remineralization of sedimentary organic matter: effects of redox oscillation. Chem Geol 114:331-345

Aller RC, Blair NE, Xia Q, Rude PD (1996) Remineralization rates, recycling, and storage of carbon in Amazon shelf sediments. Cont Shelf Res 16:753-786

Alongi DM (1989) The role of soft-bottom benthic communities in tropical mangrove and coral reef ecosystems. Rev Aquat. Sci 1:243-280

Alongi DM (1998) Coastal ecosystem processes. CRC Press Boca Raton

Alongi DM (2000) The influence of mangrove biomass and production on biogeochemical processes in tropical macrotidal coastal settings. In: Aller JY, Woodin SA, Aller RC (eds) Organism-sediment interactions. University of South Carolina Press, Columbia (in press)

Alongi DM, Boto KG, Robertson AI (1992) Nitrogen and phosphorus cycles. In: Robertson AI, Alongi DM (eds) Tropical mangrove ecosystems. Coastal and estuarine studies No. 41. American Geophysical Union, Washington, DC, p 251-292

Alongi DM, Sasekumar A, Tirendi F, Dixon P (1998) The influence of stand age on benthic decomposition and recycling of organic matter in managed mangrove forests of Malaysia. J Exp Mar Biol Ecol 225:197-218

Alongi DM, Tirendi F, Dixon P, Trott LA, Brunskill GJ (1999a) Mineralization of organic matter in intertidal sediments of a tropical semi-enclosed delta. Estuar Coast Shelf Sci 48 : 451-467

Alongi DM. Tirendi F, Trott LA (1999b) Rates and pathways of benthic mineralization in extensive shrimp ponds of the Mekong delta, Vietnam. Aquaculture, 175:269-292

Ball MC (1988) Ecophysiology of mangroves. Trees (Berl) 2: $129-142$

Boto KG (1992) Nutrients and mangroves. In: Conneil DW, 
Hawker DW (eds) Pollution in tropical aquatic systems CRC Press, Boca Raton, p 129-145

Cabrita MT, Catarino F, Vale C (1999) The effect of tidal range on the flushing of ammonium from intertidal sediments of the Tagus estuary, Portugal. Oceanol Acta 22: 291-302

Capone DG (1993) Determination of nitrogenase activity in aquatic samples using the acetylene reduction procedure In: Kemp PF, Sherr BF, Sherr EB, Cole JJ (eds) Aquatic microbial ecology. CRC Press, Boca Raton, p 621-631

Cline JD (1969) Spectrophotometric determination of hydrogen sulfide in natural waters. Limnol Oceanogr 24: $454-458$

DeGraaf GJ, Xuan TT (1998) Extensive shrimp farming, mangrove clearance and marine fisheries in the southern provinces of Vietnam. Mang Salt Marsh 2:159-166

Dixon, RK, Brown S, Houghton RA, Solomon AM, Trexler MC, Wisniewski J (1994) Carbon pools and flux of global forest ecosystems. Science, NY 263:185-192

Duarte CM. Geertz-Hansen O, Thampanya U, Terrados J, Fortes MD, Kamp-Nielsen L, Borum J, Boromthanarath S (1998) Relationship between sediment conditions and mangrove Rhizophora apiculata seedling growth and nutrient status. Mar Ecol Prog Ser 175:277-283

Fenchel T, King GM, Blackburn TH (1998) Bacterial biogeochemistry. Academic Press, San Diego

Ferdelman TG, Lee C, Pantoia S, Harder J, Bebout BM, Fossing $H$ (1997) Sulfate reduction and methanogenesis in a Thioploca-dominated sediment off the coast of Chile. Geochim Cosmochim Acta 61:3065-3079

Field CD (1995) Journey amongst mangroves. International Society for Mangrove Ecosystems, Okinawa

Folk RL (1974) Petrology of sedimentary rocks. Hemphill's, Austin, TX

Fossing HR, Jørgensen BB (1989) Measurement of bacterial sulfate reduction in sediments: evaluation of a single-step chromium reduction method. Biogeochemistry 8:205-222

Hedges JI, Bergamaschi BA, Benner R (1993) Comparative analyses of DOC and DON in natural waters. Mar Chem 41:121-134

Hinrichsen D (1998) Coastal waters of the world: trends, threats, and strategies. Island Press, Washington, DC

Hong PN, San HT (1993) Mangroves of Vietnam. The IUCN Wetlands Programme, Bangkok

Howarth RW (1993) Microbial processes in salt-marsh sediments. In: Ford TE (ed) Aquatic microbiology: an ecological approach. Blackwell, Boston, p 239-259

Howarth RW, Marino R, Lane J, Cole JJ (1988) Nitrogen fixation in freshwater, estuarine, and marine ecosystems. 1. Rates and importance. Limnol Oceanogr 33:669-687

Ishimatsu A, Hishida Y, Takita T, Kanda T, Oikawa S, Takeda T, Huat KK (1998) Mudskippers store air in their burrows. Nature, Lond 391:237-238

Johnston DJ, Clough BF, Xuan TT, Phillips M (1999) Mixed shrimp-mangrove forestry systems in Ca Mau Province, Vietnam. Aquaculture Asia 4:6-12

Kerner M, Wallmann K (1992) Remobilization events involving $\mathrm{Cd}$ and $\mathrm{Zn}$ from intertidal flat sediments in the Elbe estuary during the tidal cycle. Estuar Caast Shelf Sci 35: 371-393

Kristensen E, Devol AH, Ahmed SI, Saleem M (1992) Preliminary study of benthic metabolism and sulfate reduction in a mangrove swamp of the Indus Delta, Pakistan. Mar Ecol Prog Ser 90:287-297

Kristensen E, Holmer M, Banta GT, Jensen MH, Hansen K (1995) Carbon, nitrogen and sulfur cycling in sediments of the Ao Nam Bor mangrove forest, Phuket, Thailand: a review. Res Bull Phuket Mar Biol Cent 60:37-64

Kristensen $E_{\text {, Jensen }}$ MH, Banta GT, Hansen K, Holmer M. King GM (1998) Transformation and transport of inorganic nitrogen in sediments of a southeast Asian mangrove forest. Aquat Microb Ecol 15:165-175

Lord CJ III (1982) A selective and precise method for pyrite determination in sedimentary materials. J Sediment Petrol $52: 664-666$

Middelberg JJ, Nieuwenhuize J, Slim FJ, Ohowa B (1996) Sediment biogeochemistry in an East African mangrove forest (Gazi Bay, Kenya). Biogeochemistry 34:133-155

Nedwell DB, Blackburn TH, Wiebe WJ (1994) Dynamic nature of the turnover of organic carbon, nitrogen and sulfur in the sediments of a Jamaican mangrove forest. Mar Ecol Prog Ser 110:223-231

Nowicki BL (1994) The effect of temperature, oxygen, salinity, and nutrient enrichment on estuarine denitrification rates measured with a modified nitrogen gas flux technique. Estuar Coast Shelf Sci 38:137-156

Raich JW, Nadelhoffer KJ (1989) Belowground carbon allocation in forest ecosystems: global trends. Ecology 70: $1346-1354$

Raich JW, Schlesinger WA (1992) The global carbon dioxide flux in soil respiration and its relationship to vegetation and climate. Tellus 44:81-99

Rickard D, Schoonen MAA, Luther GW III( 1995) Chemistry of iron sulfides in sedimentary environments. In: Vairavamurthy MA. Schoonen MAA (eds) Geochemical transformations of sedimentary sulfur. American Chemical Society, Washington, DC, Ser 612, p 168-193

Ridd PV (1996) Flow through animal burrows in mangrove creeks. Estuar Coast Shelf Sci 43:617-625

Rivera-Monroy VH, Twilley RR (1996) The relative role of denitrification and immobilization in the fate of inorganic nitrogen in mangrove sediments (Terminos Lagoon, Mexico). Limnol Oceanogr 41:284-296

Robbins JA, Gustinis J (1976) A squeezer for efficient extraction of pore water from small volumes of anoxic sediment. Limnol Oceanogr 41:284-296

Ryle VD, Wellington JT (1982) Reduction column for automated determination of nitrates. Australian Institute of Marine Science, Townsville, Queensland (Analyt Lab Note No. 19)

Ryle VD, Mueller HR, Gentien P (1981) Automated analysis of nutrients in tropical seawater. Australian Institute of Marine Science, Townsville, Queensland (Aust Inst Mar Sci Oceanogr Ser OS-81-4)

Shaiful AAA (1987) Nitrate reduction in mangrove swamps. Malays Appl Biol 16:361-367

Shaiful AAA, Abdul Manan DM, Ramli MR, Veerasamy $R$ (1986) Ammonification and nitrification in wet mangrove soils. Malay J Sci 8:47-56

Sokal RR, Rohlf FJ (1995) Biometry. The principles and practice of statistics in biological research, 3rd edn. WH Freeman \& Company, New York

Spalding M, Blasco F, Field C (1997) World mangrove atlas. International Society for Mangrove Ecosystems, Okinawa

Thuy NN (1988) Tides in the Vietnam estuaries. Marine Hydrometeorological Center, Science \& Technical Publishers, Hanoi (in Vietnamese)

Wolanski E, Wattaayakorn G, King B (1996) Water circulation and pollution transport in the Gulf of Thailand. In: Nontji A (eds) Proceedings of the third international IOCWESTPAC Symposium. Research \& Development Centre for Oceanology, Indonesian Institute of Science, Jakarta, p 392-410 